\title{
Cold Spray as an emerging technology for biocompatible and antibacterial coatings: State of Art
}

\author{
A.M.Vilardell", N.Cinca, A.Concustell, S.Dosta, I.G.Cano, J.M.Guilemany
}

\section{Introduction}

The massive increase in human aging has affected different areas such as economical, social and health, especially the last one, with the increase of chronic diseases. It is anticipated that elderly people ( +65 years) will reach up to $20 \%$ of European population in 2050 , compared with the $10 \%$ of nowadays [1]. For centuries a diseased tissue was removed to improve marginally the quality of life. With the scientific advances in biomedical field however, it has led to an increase in human survivability aversely to the quality of tissues, thus the arising need to replace tissues [2]. In terms of orthopaedics, more and more patients will require the use of prostheses in order to replace critical parts of the skeletal system.

Current patients complaint about conventional prostheses include: (i) socket-related problems of discomfort, sores, rashes, and pain, (ii) the difficulties on donning the prosthesis, (iii) the unreliability of prosthesis being securely suspended and, (iv) mobility difficulties. While innovation on new materials with better mechanical and biological properties is day by day carried out through the collaboration of many scientific disciplines, the osteointegration by the surface modification of conventional prosthetic materials can still offer many possibilities for the improvement of bone reabsortion decreasing the allergenic response. In addition, in many cases, the surgery for prosthesis replacement is extremely aggressive and the cost is high; therefore, whatever solution that can extend the prosthesis life will be very welcome by clinical community.

The biomaterials field is always under development and has experienced considerable progress especially over the last $60-70$ years $[3,4]$. The definition of a biomaterial, currently proposed as "a non-viable material, used in a medical device, intended to interact with biological systems" was definitely established by William D.F in 1987 [5]. The development of biomaterials for medical applications has evolved through three generations, each with a distinct objective (Fig.1). Specific familiar terms such as 
bioinert, bioactive or biodegradable allow their classification according to their characteristics within the body.

Bioactive materials are an intermediate between resorbable and bioinert (Fig.2) [6]. The first denoted bioactive material was Bioglass ${ }^{\circledR}$, also known as 45S5 bioactive glass in the late 1960s by Larry Hench [7] and the concept of using synthetic resorbable ceramics as bone substitutes was introduced in 1969 [8] then hydroxyapatite (HA) as well as some other glass-ceramics appeared within the market circa $1985 \mathrm{~s}[9,10]$. Bioactive materials are classified in two categories: (i) Osteoproductive materials, that are recognized by the intracellular and extracellular responses elicited at their interfaces (e.g Bioglasses) whereas, (ii) Osteoconductive materials only elicit an extracellular response at their interfaces (e.g. Hydroxyapatite). Bioglasses induce integration between bone and implant in the form of a continuous interfacial layer, while osteoconductivity only induces bone growth directly at the implant surface and often results in a fibrous capsule between the implant surface and bone.

The two primary issues in biomaterials are: biocompatibility and structural compatibility [11]. Considering the biocompatibility as "the ability of a material to perform with an appropriate host response in a specific application" [5], it implicitly refers two terms: biosafety and biostability, where the material does not have to provoke chronic inflammation/infection that may cause cell death or produce a disfunction in cellular and tissue matrix [12]. Structural compatibility refers to mechanical properties and becomes especially important for prosthesis biomaterials.

Surface characteristics such roughness [13] and porosity [14] influence cell attachment and promote bond in growth fixation between implant and host issues due to its structure and free surface. The concept of bioactivity is actually highly related with those characteristics, which will be many times addressed along this paper.

\subsection{Surface treatments and biocompatible coatings: current status}

Surface engineering has helped to biomedical science to provide better understanding of implant-tissue interactions; the surface modification methods include both, the chemical modification and surface roughness as well. The atoms on the surface are more prompt to undergo phase transformations, crystallization or corrosion (dissolution) processes; this higher energy and higher reactivity are particularly important in view of adsorbates 
from the biological system. Cellular activity, protein adsorption or tissue response has been specially induced in titanium-based alloys by surface roughening, acid treatment, anodization and coating techniques i.e. thermal spraying, etc., methods that produce surface topography changes mainly at the microscale level [15]. Other attempts to improve osteoblast activity include the promotion of surface roughness with combined micrometer and nanometer structures such as photo, electron beam and colloidal lithography or electrochemical anodisation $[12,16]$.

Concerning metal coatings, Vacuum Plasma Spraying (VPS) is, for example, widely used to prepare rough and porous titanium coatings [17-21]. Yang et al. [17] obtained titanium (Ti) coatings on Ti substrates consisting of an outer layer full of macropores with a surface roughness of approximately $\mathrm{Ra}=100 \mu \mathrm{m}$ (such macropores are reported to be beneficial for tissue ingrowth into the coating), a middle layer consisting of a mixture of micropores and macropores and, an inner dense layer. By contrast however, Borsari et al. [19] used the same technique to produce rough but dense VPS-Ti coatings with the purpose of avoiding as much the reduction in bone density, also known as "stress shielding", as possible, and thus prolong the prosthesis lifespan. The aim of that study was to investigate the in vitro effect of high roughness $(\mathrm{Ra}=73.75 \mu \mathrm{m})$ and dense $\mathrm{Ti}$ surface in comparison with medium $(\mathrm{Ra}=18.42 \mu \mathrm{m})$ and high roughness $(\mathrm{Ra}=39.64 \mu \mathrm{m})$ and open porous coatings. Such new ultra-high rough and dense VPS coating provided a good biological response; at least in vitro, it behaved similarly to the coatings already used in orthopedics. The effect of the coating stability and ultra-high roughness level after surgical implantation and during dynamic bone healing and remodelling has yet to be established. Other titanium coatings for medical devices include, open-porosity, porosity, mixtures of bioactive feedstock powders materials.

Other Thermal Spray (TS) metal coatings attempts include tantalum (Ta) and silver (Ag). Tantalum coatings have an excellent corrosion, good formability, low coefficient of expansion, excellent wear resistance and excellent biocompatibility and radio-opacity for biomedical applications. Recent in vitro, in vivo, and clinical studies demonstrated that tantalum is a promising bioactive metal [22,23]. Since tantalum applications in biomedical devices have been limited by processing challenges rather than biological performance, Ta coatings have been achieved via Plasma Spray (APS) and High Velocity Oxy Fuel (HVOF). Optimizing spraying parameters lead to minimum porosity and oxide content but without good corrosion protection [22,23]; in addition, there are 
still some drawbacks such the high cost and the high reactivity at temperatures above $500^{\circ} \mathrm{C}$ where oxidation causes loss of ductility and cracking of the surface material. Other coating methods by which tantalum has been deposited include LENS ${ }^{\text {TM }}$ (Laser Engineered Net Shaping) [24], sputter deposition [25], chemical vapor deposition (CVD) and electrodeposition.

From another hand, silver has been highlight since ancient times for its antibacterial, antifungal and antiviral properties; also its compounds such as silver nitrate and silver sulfadiazine, have been used for the treatment of burns, wounds and several bacterial infections [26-28]. Pure silver coatings by different methodologies have been tested with very good results, especially in catheters [29-34]. Using thermal spray methods however, silver has been codeposited with many other materials [35-39]. For example, Hydroxyapatite/Silver composite coatings obtained via VPS proved to combine antibacterial and bioactivity properties; it was found non cytotoxicity for the coatings and they were covered by bone-like apatite layer after immersed in Simulated Body Fluids (SBF), suggesting that their bioactivity was not affected obviously by the addition of silver in the coatings [40].

Concerning ceramic coatings, plasma sprayed alumina and zirconia are being used clinically, mostly due to their higher wear resistance than titania. However, alumina and zirconia coatings cannot bind directly to bone tissues due to their bio-inert nature, thus limiting their use in hard tissue applications. Moreover, there is a controversy on the binding strength and on particle release from plasma sprayed coatings into the host tissue, caused by either dissolution or fretting. Therefore, the use of bioactive hydroxyapatite (HA) coatings produced by plasma spraying (APS) [41-44], high velocity oxy-fuel (HVOF) [45-47] and flame spray as well [48] was a very successful achievement; in HVOF, particles reach lower temperatures and higher velocities that minimize the time of residence of the particles within the spray beam and therefore its thermal decomposition $[1,49]$. HA-coated prosthesis maximize fixation and decrease the migration of microparticles along the prostheses [50]; they are a good alternative to cemented prosthesis, which have high rates of loosening. In addition, Chern et al. [51] compared the coating-substrate bonding strength of HA with other bioactive coatings such as bioglass, bioglass-HA and found that bonding strength was 33,0 $0 \pm 4,3,39,1 \pm 5,0$, $52 \pm 11,7 \mathrm{MPa}$ for bioglass, bioglass-HA and HAcoatings respectively. It was demonstrated that after 4 weeks bone ingrowth was significantly higher in bioglass and 
HA coatings but after 16 weeks only bioglass maintained its highs percentages of bone ingrowth while in HA decreased with time [52]. Despite having excellent bioactivity, the mechanical properties of bioactive glasses are worse than bioactive HA; this problem can be solved by combining those bioactive materials with metals or polymers to produce a composite coating surface [53]. Cai et al. [54] developed a sintered Co-Cr$\mathrm{Mo} /$ Bioglass composite coating for medical implant application in order to be compared to plasma sprayed coatings. Those coatings show a more porous structure than plasma spray but less wear resistance. Nevertheless, an adequate bonding between Co-CrMo/Bioglass composite coating was achieved and furthermore a apatite layer on top of the coating performed bioactivity. Moreover, more processes are used to fabricate composite bioglass coatings, such as sol-gel[55], electrophoeric deposition [56] and pulsed laser deposition [57].

Even enhanced biocompatibilities are achieved by using nanocrystalline ceramics [58,59]. HA particles shape has a high influence in cells performance (e.g: needle shaped particles promote inflammatory reaction, spherical shaped particles show increase inhibition with time and concentration of those in U2-OS cancer cells, and irregular shaped particles produced a greater response than spherical shaped particles).

However, there is still some concern about the uniformity, the adherence of the coatings and the dissolution rates due to crystalline issues affecting long-term stability. The lack of uniformity is related to the uncontrollable crystallinity within HA plasma coatings, leading to many different phases such as alpha tricalcium phosphate $(\alpha-\mathrm{TCP})$, beta tricalcium phosphate ( $\beta$-TCP), tetracalcium phosphate (TTCP), Oxyapatite (OHA) and amorphous phases (ACP), whereas the concern on the adherence is attributed to the presence of amorphous phases at the coating-substrate interface. Ceramic bond coats based on zirconia and titania have been plasma sprayed in order to be employed to act as chemical barrier against in vivo release of metal ions from the implant and improve the adhesive bond [60]. Table 1 includes the requirements of HA coatings for implants for surgery specified by different ISO and ASTM standards [61-65].

Other coating technologies have also been employed for the production of HA coatings but compared to thermal spray processes (TS) are less cost-effective. Table 2 shows some advantages and disadvantages of TS compared to such other possibilities. 
Some other variations of these type of coatings have been performed such as by using $\mathrm{HA}-\mathrm{TiO}_{2}$ mixtures to improve mechanical properties i.e. bond strength, fracture toughness and wear resistance [70-72], fluoroapatite-HA mixtures given that fluorapatite offers the potential for lower mineral ion release by dissolution [73], yttria stabilized zirconia reinforced $\mathrm{HA} / \mathrm{Ti}-6 \mathrm{Al}-4 \mathrm{~V}$ composites which leads to significantly higher mechanical properties than pure HA coatings (even after immersion in SBF solution) [74], Ta/HA layers to improve the corrosion resistance and biocompatibility [75], Ag-HA mixtures to reduce bacterial adhesion [76-78] or by using carbon-nanotube reinforcement imparting strength and toughness to brittle HA bioceramic coating [79].

All these surface modifications have been developed over the past decades to improve the bioactivity mostly of Ti-based implants and its bonding strength to the host tissue. However, although many research groups are still working on this topic, there has been more recently an upgrade on the study of polymer composite materials as an alternative choice to overcome the shortcomings of metals and ceramics [4]. The poly(ether ether ketone) (PEEK), for example, highlights for its biocompatibility, bioinertness and similar elastic modulus to the bone and, their good mechanical properties for hard tissue applications (hip and knee replacements) [80]; other polymers such as Poly(lactic acid) PLA -bone plates, tendons and ligaments- and poly-L-lactide (PLLA) -bone platesstand out for their fully resorbable property; Polyurethane (PU) and Silicone Rubber (SR) get distinguish because of their flexibility in catheters. Some of the attempts to improve the bioactivity of these polymers include coating with tantalum [81], gold, titanium dioxide $\left(\mathrm{TiO}_{2}\right)$, diamond-like carbon (DLC), and tert-butoxides [82].

The bioactivity requirement, depending on the component application, can be also pursued by proper manufacturing routes [83]. In this direction, some researchers have developed human hip joint prosthesis made of fiber reinforced poly(ether ether ketone) (CF/PEEK) and coated the stem with Vacuum Plasma Sprayed (VPS) Ti/HA coatings [84]; the mechanical tests of the prosthesis produced by Riner et al. indicated good long term stability of the bone-prosthesis system, while the in-vitro and in-vivo tests proved no cytotoxicity and necrotic effects in rabbits. Apart from plasma spraying, HA coatings have been also produced on PEEK substrates by other processes such as RF magnetron sputtering and aerosol technique.

\subsection{Biocoatings market for orthopaedic implant with focus on thermal spray}


As schemed in figure 1, after the first generation of load-bearing implants (cortical bone substitution) by using bioinert materials (stainless steel $316 \mathrm{~L}$, cobalt chromium alloy, titanium, or titanium alloy $(\mathrm{Ti}-6 \% \mathrm{Al}-4 \% \mathrm{~V}))$, the second generation involving surface treatments, emerged prominently in 1985 with the first HA-coated femoral prosthesis (Furlong®), JRI, London, UK) [85]. In general, in-vitro and in-vivo studies indicate that bioactive biomaterials application in biomedical field increase the long-term durability of prostheses. Since first clinical reported trials of HA coatings on femoral stems, HA coatings were extensively used in dental and orthopedic prosthesis [86]. HA coatings are currently being used in total hip [87,88] and knee [89] replacement implants, ankle and shoulder implants, screws and pins in bone plates for fixing bone fractures. Medical studies were done such acetabular cups in total hip arthoplasty [90] and tibial component in total knee arthoplasty [91] at a minimum duration of follow-up of five years comparing different fixations, like HA coatings, porous surfaces and cemented fixations. HA-coatings surfaces stabilized after an initial period of early migration, whereas cemented components showed an initially lower, but over time continuously increasing migration. Some of biomaterials used in skeletal system applications are shown in table 3 together with medical market.

At the moment, some of the successful bioactive coatings for implants have been produced by electrodeposition and plasma spraying: Peri-apatite $^{\mathrm{TM}}$, Biomet's Osteocoat ${ }^{\circledR}$, Corail ${ }^{\circledR}$, among the most important. Other successful approaches have been: (i) the development of a macro-sized interconnected porosity in the range of 100$500 \mu \mathrm{m}$ within a metal coating with the aim to promote proper bone ingrowth i.e. Regenerex $^{\mathrm{TM}}$, Trabecular Metal $^{\mathrm{TM}}$, Arcam AB Trabecular Structures ${ }^{\mathrm{TM}}$ and (ii) nanoscale topographies i.e. OsseoSpeed ${ }^{\mathrm{TM}}$, Nanotite ${ }^{\mathrm{TM}}$. Table 4 presents some of the characteristics of the current commercial orthopedic implants [92].

\section{Thermal spray processes}

\subsection{Conventional technologies}

TS is a group of techniques to produce metallic and non-metallic coatings where the feedstock is sprayed in molten or semimolten state onto a prepared substrate. Their basic principle is to impart sufficient kinetic and thermal energy to the raw material (in powder, wire or rod form) to create a confined high-energy particle stream, and propel the energetic particles toward the substrate. Through the solidification of the droplets on 
impact with the substrate, they create cohesive bonds with each other and adhesive bonds with the substrate; many different spraying parameters need to be optimized to produce suitable coatings for the desired applications (Fig. 3).

The particles are heated by electrical (air plasma or arc wire spraying) or chemical (detonation gun, flame spraying or high velocity oxy fuel) means. Droplets impact and start bonding onto substrate due to high cooling rate, typically excess of $10^{6} \mathrm{~K} / \mathrm{s}$ for metals [93-95]. Coating properties directly depend on particle temperatures and speeds, which produce thin layers o lamellas, often, called "Splats", that finally buildup the deposit. There are three types of bonding mechanisms at interface substrate-coating, being predominant the mechanical bonding followed by metallurgical ones [95]:

- Mechanical bonding, particles, molten or semi-molten, impact onto surface substrate (previously grit-blasted) and remain adhered due to its roughness.

- Metallurgical bonding, given by the occurrence of interdifusion processes between substrate-coating and even though the formation one new compounds such as intermetallic phases.

- Physical bonding, reached by Van deer Waals forces between substrate-coat.

Thermal Spraying techniques are divided in three subgroups according to the energy source (Fig.4) and the selection of the appropriate spraying method will be determined by: coating material characteristics, coating performance requirements, economics and, part size and portability.

\subsubsection{Advantages of conventional technologies}

A big advantage of thermal spray processes is the ability to deposit an extremely wide range of materials. Virtually any material that has a stable molten phase can be deposited, and even some materials that do not melt, such as graphite and many carbide or boride ceramics, can often be co-deposited with another sprayable material to create a composite coating material. Another one is that the range of suitable substrate materials is even greater that the range of sprayable materials. In addition to metals, ceramics, glasses, and polymers, thermal spray coatings have been successfully applied to many other substrate materials including wood. Conventional thermal spray also offers the advantage of high deposition rates, which are orders of magnitude higher than those of 
most alternative coating technologies, such as electroplating or vapor deposition, where deposition occurs at the atomic or molecular level. When the objects to be coated are very large or difficult to move, the ability to apply coating is in-situ, is also an advantage. Furthermore, coatings can be applied without significant heat input and it is possible to strip off and recoat worn or damaged coatings without changing part properties or dimensions. Further advantages of Thermal Spraying include its rapid coating deposition, low-cost, high efficiency and rapid execution process.

Although all the techniques exposed in table 2 are suitable to produce bioactive HA layers, only thermal spraying, in particular, plasma spraying is the commercially accepted method by Food and Drug Administration (FDA), USA for producing hydroxyapatite coatings [96].

\subsubsection{Limitations of conventional technologies}

TS deposition features depend on the used technique and, the thermal and kinetic applied energy will be different. High temperatures cause oxide inclusions (overcoat metallic materials) as well as decomposition/degradation in oxygen-sensitive materials such titanium or HA respectively. Oxide inclusions improve mechanical properties like wear resistance and hardness, but an excessive presence at intersplat regions lead to cohesive failure and wear debris [97]. Processes that minimize heating of the spray material, such as HVOF and D-Gun, typically result in lower oxide concentration and minimal changes in alloy chemistry. Also, the controlled inert atmosphere of VPS creates very little or no oxide during the deposition process; however, some changes in the alloy chemistry may still occur due to relatively high temperatures in the plasma jet. High porosity could be beneficial in some applications like in the case of prosthesis to promote a good bone ingrowth; conversely, excessive porosity can also be a problem if the coating is intended to protect the underlying substrate from species that can cause corrosion or other problems. Porosity depends more over on size particle distribution and spray distance, producing "unmelted" particles according to their inertia when are fed into the plume. Also, low-velocity processes tend to have higher level of porosity in the range of $5-15 \%$ volume, and higher velocity processes origin coatings with less porosity (3-8\% volume). Another limitation is the introduction of residual stresses that limits the maximum thickness due to the solidification of droplets when they cool down 
[98]. Finally, the deposition is limited to surfaces in a direct line-of-sight of the spray gun.

Cold Spray (CS), a novel spray technique in the late of 1980s, mainly arises from the limitations of some coating types of thermal spray that seem to be overcome for some materials. $\mathrm{CS}$ is a low-temperature process based on the plastic deformation of the spraying material and it is suitable for the deposition of oxygen-sensitive materials, or for temperature sensitive materials like nanostructured and amorphous powders [97100]. Moreover, it should also be noticed that, compared to the conventional thermal spray technologies and other coating alternatives like painting and electrodeposition, cold spray is an environmental friendly approach since its effluents are easy to control and to dispose and it is a non-combustion process.

\subsection{Cold Spray technique}

Cold Spray (CS) is newest recent spray technology from the thermal spray family from 1980s; it is based on the kinetics energy and stands above conventional spray techniques for its low temperature rates. Small particles $(5-50 \mu \mathrm{m})$ are accelerated by a pre-heated gas temperature $\left(25-1100^{\circ} \mathrm{C}\right)$ lower than the melting point of the material and propelled towards a prepared substrate at supersonic velocities $(300-1200 \mathrm{~m} / \mathrm{s})$. Supersonic flows from gas dynamics are obtained within nozzle with the principal purpose to maximize the thrust and obtain a better coating quality. Nozzle design influences on particle velocity, depending basically on the type of nozzle and its geometry. From the three basic nozzles: Convergent-barrel (CB nozzle), convergent-divergent (CD nozzle) and convergent-divergent-barrel (CDB nozzle), the one who achieves a higher particle velocity is CD nozzles, known also as Laval nozzle with its conical geometry.

Particle binding is made by kinetics energy when particle impacts onto a surface causing plastically deformation [98], becoming particle velocity an important parameter. Due to high kinetics, CS is able to produce quality dense coatings. However, depending on spraying conditions a particle size, it is able to obtain porous coatings. Figure 5 shows a schema of CS technique.

Instantly, the feedstock located in the feeder is propelled by gas (normally $\mathrm{N}_{2}$ ), and preheated gas $\left(\mathrm{N}_{2}\right.$, Air or helium) at determinate temperature and pressure, into the spray 
nozzle, to propel particles at high velocities to buildup the coating. Stages of coating formation are shown in figure 6 [101].

\subsubsection{Advantages of CS technology}

The main advantage of the cold spray process is that it is a solid-state process, which results in many unique coating characteristics. High deposition efficiency values have been achieved with metals, alloys and composites; high deposition rates can produce a thick coating in a single pass $(1-2 \mathrm{~mm})$ due to its typical spray beam of about $10 \mathrm{~mm}$ of diameter [98].

CS can be viewed as a triplex process (grit blast, spray coat and shot peen), as is to be expected caused by the velocity Gaussian distribution across the spray beam; flexibility in substrate-coating selection is good to produce coatings that could lead to unacceptable interfaces in APS or HVOF that i.e intermetallic phases between $\mathrm{Cu}-\mathrm{Al}$ with APS; minimum thermal input to the substrate facilitates the use of temperature and oxygen sensitive materials such magnesium, titanium and polymers. Moreover, residual tensile thermal stresses remain in a TS coating produced by a conventional process, whereas CS induce stresses mostly in compressive nature across the entire coating thickness, which improves mechanical properties such as fatigue. However, some investigations confirm that in specific cases neutral and tensile stresses may appear depending on substrate/coating combination and surface treatment. Suhoen et al. [102] deposited $\mathrm{Al}$, Ti and $\mathrm{Cu}$ onto carbon steel (CS), SS and Al substrates with different surface treatments. It has been shown that compressive residual stresses predominate in $\mathrm{Cu}$ deposition onto the majority of the specimens; also Ti coatings may show compressive, neutral or tensile residual stresses depending on the substrate; by contrast, Al coatings exhibited tensile residual stresses onto all the substrates.

Furthermore, compressive residual stresses may be detrimental if relatively thick coatings are sprayed onto thin substrates and they produce their deformation; also, they have to be taken into account in the case that they promote tensile stresses to the substrate. Therefore, residual stresses should be considered in any application where structures are required to carry load.

It has been demonstrated that metals, polymers, ceramics and composite materials are able to be applied with CS technology in a wide range of applications that are in 
constant development, such as those involving corrosion protection, repairing structures, catalyst deposition, electromagnet transition, electronic and medical devices $[103,104]$.

Depending on spraying materials properties, grid blasting could be a good option to improve particle attachment onto substrate if a mechanical anchoring effect contributes in the bonding mechanism $[105,106,107]$. However, it might be detrimental if this induces hardening of the substrate surface since it would change the mechanical surface characteristics $[108,109,110]$.

\subsubsection{Process parameters of CS technology}

The actual mechanism by which the solid particles deform and bond during CS is still not well understood. Particles undergo to an extensive plastic deformation when impact onto the substrate, which results in the creation of jets, known as Adiabatic Shear Bands (ASB), in the case of ductile materials such metals. It is believed that the contact of substrate surface and particle with the high pressures is necessary for particle bonding. Actually, for metals which are the mostly deposited materials by CS, the resulting microstructure resembles to that of a cold worked material, with elongated grains and even recrystallized areas at particle interfaces where a higher temperature is reached a result of adiabatic shearing [111]; such microstructures have been well compared to those of powder compacted and explosive welded materials. A wide range of ductile materials (metallic and polymeric) have been successfully deposited by CS, whereas non-ductile materials such as ceramics are able to deposit onto ductile substrates where particle could be embedded.

Generally, for each material, there is a critical velocity $(\mathrm{Vc})$ for its successful deposition onto a certain substrate. Only those particles that exceed this critical velocity $(\mathrm{Vp}>\mathrm{Vc})$ will be successfully deposited to build up a coating, but higher impact velocities may results in erosion of surface substrate.

This critical velocity depends, from one side, on the intrinsic characteristics of the spraying material i.e. the physical and mechanical properties such as density, melting point and ultimate strength and, from another side on the particle size, morphology, temperature and substrate; in addition, the particle velocity $(\mathrm{Vp})$ also depends on the 
spray gun parameters i.e gas composition, gas preheat temperature, gas pressure and nozzle geometry. An optimization of all these parameters is many times critical for a good deposition [100].

Metal, cermet and polymeric coatings have been successfully produced onto different substrates, but ceramic coatings are still a challenge due to its intrinsic brittleness. Blends of metal-ceramic feedstock powders have been sprayed by CS leading to improved coating properties such wear and hardness [112]; as it will be later discussed, this alternative has been successfully used to produce titanium-HA coatings.

\section{Biocoatings via $\mathrm{CS}$}

\subsection{Metal biocoatings}

Biocompatible metals were the first family of materials to be sprayed via CS within this field due to their high plasticities and thus the feasibility to produce coatings with good efficiencies. The first metal coatings that were used for biomedical applications were of Stainless Steel (SS) and titanium. In analogy to porous plasma sprayed titanium coatings, these have been also produced by CS with the aim to allow bone in-growth.

By changing the spraying conditions, it is posible to reach different porosity levels. Li et al. [113] presented the microstructure of cold sprayed Ti and Ti6Al4V coatings onto Ti6Al4V substrates and the effect of heat treatment on coating microstructure. These authors achieved an average porosity of $5,4 \pm 2,4 \%$ and $22,3 \pm 4,7 \%$ before the heat treatment; after the heat treatment, the porosity increased to $21,6 \pm 4,6 \%$ and $29,7 \pm 5,1 \%$ probably by the healing of the incomplete interfaces through the atom diffusion during annealing treatment. In addition, Wong et al. is another example of how the authors achieve different degrees of porosity by a wide range of modification of the spraying conditions (Fig.7) [114]. It might be also worth noting that the density of the microstructure can be influenced by the tamping effect, this is the successive impact of following particles, therefore leading to more porous structures on the top rather than near the interface with the substrate [115].

On the other hand, some authors have used materials such as magnesium or aluminum to produce porosity. Sun et al. [116] produced porous titanium coatings spraying $\mathrm{Mg}+\mathrm{Ti}$ powders onto titanium, where the magnesium behaved as space holder and is eliminated by vacuum sintering. Plasma sprayed porous titanium coatings usually exhibit irregular 
porosity distribution and the pores are not well interconnected, while other methods such as sintering titanium beads or fibers have relatively low porosity $(<37 \%)$ and low cohesive and/or bond strength. By contrast, CS coatings by Mg+Ti resulted in an average porosity of $48,6 \%$ and pore sizes in the range of 70 to $150 \mu \mathrm{m}$. Bending modulus and compressive modulus of porous titanium coating were close to the bone and thus may be beneficial to reducing stress shielding. Qiu et al. used aluminum as porogen to form porous titanium coatings [117], which was removed after spraying by alkaline leaching. Considering all test, the average pore size was between $74-91 \mu \mathrm{m}$ and the pore percentage between $48-66 \%$.. Figure 8 shows the porous morphologies and cross section of both studies with pore sizes of 50-150 $\mu \mathrm{m}$ and 70-150 $\mu \mathrm{m}$ respectively.

Furthermore, well-adhered, thick and homogeneous titanium coatings have been also produced onto PEEK biopolymer without its degradation, with the aim to enhance PEEKs biocompatibility for implant applications [118]. This responds to the new emerging use of PEEK as a novel alternative within the biomedical field. Table 5 shows the CS Spray conditions of metal coatings used for biocoatings. Spraying onto UHMWPE has also been produced with the aim to avoid having the polyethylene liner and the acetabular cup as two separate components. In such a way, the rough titanium shell and the polymer contacting the femoral head can be achieved within the same component; this was obtained through properly surface activation previous to spraying [119].

The ability to produce refined-grain coatings via $\mathrm{CS}$, due to unchanged microstructure of the feedstock powder material, has been also taken benefit in the biomedical field, specifically in coronary stents. AL-Mangour et al. [120] performed mechanical and corrosion properties in stents coated by a mixture of L605 cobalt-chromium ( $\mathrm{Co}-\mathrm{Cr})$ alloy and 316-L SS onto mild steel, where it was observed that the addition of cobalt powders helped to obtain dense coatings. A heat treatment improved then the densification and porosity reduction as well as a significant increase of ductility; also, despite in vivo and in vitro tests are still pending, the $\mathrm{Co}-\mathrm{Cr}$ alloy showed a lower corrosion rate than pure SS, making it suitable for the development of a new class of metallic biomaterials. 
Other attempts were done with Tantalum (Ta). Cold Spray (CS), as it works with low temperatures, is being studies for produce Ta coatings where it is observed good interface adhesion, low porosity and increase of hardness [121].

Finally, metal coatings have also been produced by CS for bone fracture fixation systems in order to prevent bonding or one or more types of corrosion between the metallic fastener and the metallic bone plate [122]. Where the components of an internal fixation device subsequently bond together, the surgeon may have extreme difficultly disengaging one component from the other, such as disengaging a bone screw from within an opening in a bone plate. The bonding may prevent the separation of the components and therefore, it can result in injuries due to the prevention of the components being removed from the patient. This patented procedure comprises a coldsprayed metallic coating either within the opening or on the metallic fastener. The coldsprayed metallic coating comprises a biocompatible metallic material having a third composition that is different than the first and second compositions.

\subsection{Ceramic-based biocoatings}

Specifically, bioactive ceramic coatings highlight for their direct bond to living tissues when implanted. Looking for fixation, bioactive fixation forms a bond with higher strength than mechanical fixation. Nevertheless, $\mathrm{TiO}_{2}$ coatings are currently been investigate by CGS despite its good mechanical properties and biocompatibility. Kilemann et al. [123] studied the formation of $\mathrm{TiO}_{2}$ particles onto metallic substrates. $\mathrm{TiO}_{2}$ particles interact as solid spheres with the substrate bonding in a ring-like zone. Particles breaks into small remnants remain in the bonding zones. Only if substrate material is brought to the surface and is available to bind other particles, a second layer or parts of it are likely to be attached to the coating on impact. Salim et al. [124] sprayed a novel synthesis of $\mathrm{TiO}_{2}$ powders for CS in which makes it possible the deposition of those particles by CS and the growing up of a layer without the addition of binder, but onto $\mathrm{Cu}$ not in biocompatible material. Nevertheless, investigations are currently running out.

\subsubsection{HA biocoatings}

Previously, the advantages of CS over conventional thermal spray processes have been mainly associated to high temperature-related features. HA coatings have been found to 
promote fast and enhanced fixation strength but the long-term stability of the fixation has been reported to still be a challenge in TS techniques; for this main reason CS is proposed as an alternative to produce HA coatings with high density and controlled crystallinity. In front of other low-temperature processes such as sol-gel, biomimetic deposition, solution deposition, electrochemical deposition and atomic layer deposition, HA cold spray technique highlights for its simple and economic process of producing coatings at low temperatures being able to control coatings microstructure.

Despite the common sense that HA particles bombardment is like blasting the metal surface of the implant, some approaches have been done in this direction [125-129] and even more successful by dealing with a shot-penning route [130]. Cold Gas Spray of ceramics has been actually compared to other low temperature powder-based dry manufacturing processes i.e. aerosol deposition (AD), sometimes known as vacuum cold spray (VCS) and nano-particle deposition system (NPDS), which appeared in the 1990s and 2000s respectively. $\mathrm{AD}$ is based on the acceleration of submicrometer particles but low-vacuum conditions are necessary to control the supersonic flow. In NPDS, the source of bonding is attributed to the dissipation of the kinetic energy of the particles. The use of submicrometer feedstock particles seems to be also important and some plasticity features have been revealed [131-133]. Dense hydroxyapatite coatings have been deposited on titanium by this method [134-135].

Different numerical and simulation studies have been developed to come upon optimal conditions for cold spraying of spraying HA. Zhang et al. [136] studied the factors influencing HA particle acceleration using a computational fluid dynamics program FLUENT. The simulation results showed that the HA particle is accelerated by the combination of throat diameter and exit diameter whose expansion ratios lie within the optimal range of 1.5-4. HA particle velocity increases with the increasing of gas pressure notably from $0.2 \mathrm{MPA}(150 \mathrm{~mm} / \mathrm{s})$ at $0.6 \mathrm{MPa}(360 \mathrm{~mm} / \mathrm{s})$ and with the decrease of HA particle size until a minimum of $5 \mu \mathrm{m}$, where it decelerates steeply, being $5-20 \mu \mathrm{m}$ size particle suitable for spray with CS. the taguchi method, was used by Singh [137] to optimize HA conditions in CS; they calculated the percentage contribution of all factors on exit particle velocity of HA powder, being as follows in descending order: Gas Type $>$ Particle Diameter $>$ Gas Inlet Pressure $>$ Particle Temperature $>$ Gas Inlet Temperature. Moreover, they observed the combination of those parameters can alter the result [138]; the increase of gas pressure and particle temperature was found to 
increase the particle velocity, while the increase of HA particle diameter was found to decrease the particle velocity and its influence was found to be more than respective influences of gas pressure, gas temperature and particle temperature. Therefore, HA particle velocity is inversely proportional to particle size, despite the increase of gas pressure and gas temperature.

Recent investigations concern biodegradable implants and biocompatible coatings on implant materials for example magnesium-based alloys. Despite its excellent properties magnesium-based alloys have not seen tangible applications in biomedical field industry. To date they have been studied within the development of cardiovascular stents, bone fixation material and porous scaffolds for bone repair. Nevertheless, the main limitation to the medical application is their rapidly and localized corrosion behavior. In order to control the degradation rates, it is useful to coat with HA. APS studies have not been developed for its high temperatures that could melt magnesium substrate and decompose HA in other calcium phosphate phases and the crystallinity of HA may also be lowered due to rapid solidifications. CS has offered solution to both problems [139].

On another hand, pure HA coatings have been produced on PEEK substrates by CS, therefore providing bioactivity to a material that avoids the stress shielding phenomenon normally occurring between a metallic material and the bone and, the weak mechanical properties of ceramic substrates [140]. Coating polymeric biomaterials with calcium phosphate is also one of the most effective methods to enhance biocompatibility. However, calcium phosphate ceramic coatings necessitate a heat treatment at a high temperature in order to induce crystallization of the coating layer, or necessitate a costconsuming vacuum deposition method for low temperature crystallization in order to control/obtain other calcium phosphate phases. In the case of polymeric biomaterials, a heat treatment at a high temperature brings about deformation of polymers, and such deformation eventually deteriorates the performance of polymers, preventing the polymers from being used as biomaterials. Furthermore, a vacuum deposition method at a low temperature may also damage the surfaces of polymers, causing deformation, and requires high production cost to increase productivity, which is not preferable. CS overcomes the limitations of various conventional coating methods, and enables coating of the surfaces of polymeric biomaterials while maintaining the intrinsic properties of both the powder and the polymer, with low production cost and high productivity. This 
patent includes as bioactive coatings HA, bioglass compounds such as bioglasses containing $\mathrm{CaO}, \mathrm{SiO}_{2}$ and $\mathrm{P}_{2} \mathrm{O}_{5}$ as main ingredients, and crystallized bioglasses; and mixtures thereof [140]. Lee et al. [141] also evaluated the bioactivity of HA coatings on PEEK substrates by CS; these proved to be homogeneous and strongly adhered without any deformation of the substrate material.

\subsubsection{HA-composite biocoatings}

Due to the intrinsic brittle nature of ceramics, a direct deposition of a uniform layer with proper adhesion is still a challenge via CS, specially onto the typical metallic prosthesis i.e titanium and SS, on account of the inelastic deformation that ends in failure fragmentation. This has already been observed by the few studies reported in the previous section. For a better understanding of this behavior, lots of studies are being carried out on the investigation of failure mechanisms of ceramics at dynamic impacts $[142,143]$.Significant efforts are thus addressed in the direction of using metal-ceramic and polymer-ceramic composite powders. Some works deal with HA-Ti mixtures $[144,145]$. The results showed that compared to pure Ti coating, cold sprayed HA/Ti composite coating exhibits higher corrosion current and lower corrosion resistance. However, a post spray heat treatment can improve the corrosion property of HA/Ti composite coating remarkably. In addition, the mechanical properties such as microhardness and ultimate shear strength of cold sprayed 20wt\% HAP/Ti composite coating also improved up to three times by a post spray heat treatment process. Further, the recrystallization also favoured the interfacial bonding and hence improved the mechanical properties [146]. Choudhuri et al. [147] also demonstrated that HA-Ti mixture powders can be cold sprayed achieving a better bond strength $(24.45 \mathrm{MPa})$ than APS ( 10-15MPa); two different titanium powders were used in those mixtures: a vacuum atomized commercial pure $\mathrm{Ti}(\mathrm{Cp}-\mathrm{Ti})$ and a sponge titanium powder both from a particle size $\sim 45 \mu \mathrm{m}$.

Cp-Ti showed difficulties to build up the coating by encapsulating HA particles, whereas the use of sponge Ti powder was more effective. The maximum incorporation of HA was of a $20 \%$; above that percentage, it was found that HA particles got crushed into fragments due to high impacts.

As reported before, aluminum powders have been used as a porogen, in combination with titanium, to achieve porous titanium coatings with higher interconnected 
macroporosity and larger specific surface area; in order to make these coatings bioactive, HA was added to facilitate bone cell attachment and ingrowth, leading to outstanding in-vitro HA mineralization, although long term studies are required [117]. Such authors used two types of HA, a crystalline and an amorphous calcium phosphate nanocrystalline HA (NC-HA) were it could be observed that NC-HA reach a maximum $\mathrm{Ca}^{2+}$ mineralization efficiency promoting an early bone fixation.

Other attempts, in that case of cold-sprayed HA-composite coatings include: HAgraphene nanohseet (GN) [148], with the aim to avoid the concerns related to its longterm performance, i.e., the intrinsic brittleness and low fracture toughness of HA and, doping HA with silver [149], with the advantages that silver involve. The addition of graphene has been proved to be very suitable for load-bearing applications, exhibiting a very reasonable biocompatibility as well; it was even embedded in HA matrix and plastic deformation of certain nano HA particles was revealed. The GN-containing HA coatings markedly enhanced attachment and proliferation of the osteoblast cells, which is most likely attributed to fast adsorption of key serum proteins like fibronectin with elongated stretching conformation on GN. Table 6 shows different cases CS conditions for biomedical applications.

\section{Clinical performance}

This is a very novel topic and since many few researchers have optimized their coating systems, not many in-vitro and in-vivo results exist within the literature. In-vitro performance can be evaluated by the evaluation of morphological changes of coatings after immersion in SBF. Qiu et al. reported the formation of clusters of fine precipitates for their HA-Ti porous coatings, with similar calcium mineralization efficiencies when using either crystalline HA or amorphous nanocrystalline HA [117]. In addition, these authors used the human osteosarcoma-derived SaOS-2 line with the aim to evaluate the cytotoxicity; cell viabilities after $48 \mathrm{~h}$ proved that neither of the coatings was cytotoxic.

On another hand, Gardon et al. [150] studied the differentiation and proliferation of cultured trabecular bone of $\mathrm{Ti}$ coatings onto PEEK obtaining a better biological response from Ti than PEEK from 3 days of culture, although optimal properties were shown with nanostructured titanium dioxide. Lee et al. [136] performed similar studies with cultured Human bone marrow mesenchymal stem cells hBMSCs (Human Bone Marrow Stromal Osteoprogenitor Cells) on HA-CS coated PEEK samples. The HA 
coating facilitated the differentiation and proliferation of cultured hBMSCs and promoted bone fusion with the surrounding iliac bone without the presence of any fibrous layer. Figure 9 illustrates some in-vivo results showing an association of the cylinders with the bone tissue improved as the recovery period in HA-coated PEEK disc group was increased. In contrast, the association of the cylinders with the bone tissue decreased for the animals implanted with the bare PEEK cylinder. Noorakma et al. [139] deposite an hydroxyapatite layer onto magnesium alloy substrate and demonstrates that In vitro behavior, superior cells adherence with numerous cellular micro extensions on porous Ta samples compared to Ti samples clearly suggests that $\mathrm{Ta}$ surfaces are biocompatible and cause no inhibition to bone cells (hFOB) adhesion and growth. Presence of relatively high ECM (Extra Cellular Matrix) mineralization on porous Ta samples also indicates that osteoblast cells have started differentiating and ECM remodeling [151]. In vivo, this porous tantalum biomaterial has desirable characteristics for bone ingrowth; further studies are warranted to ascertain its potential for clinical reconstructive orthopaedics [152].

The addition of graphene to HA coatings significantly enhanced attachment and proliferation of human osteoblast cells, which is most likely attributed to fast adsorption of key serum proteins like fibronectin with elongated stretching conformation on graphene [143].

\section{Antibacterial/Antimicrobial coatings}

Although the use of titanium and its alloys in biomedicine is still important, the infection around the implants remains as a concern. Infection not only do the patients suffer serious damage but bacterial infection after implant placement can cause significant complications thereby increasing medical cost. The paradigm of bacterial attachment and proliferation on surfaces was first recognized in the 1930s. It was established that a bacteria prefer to colonize a solid substrate than living in a planktonic state. The creation of antibacterial surfaces seeks to repel or resist the initial attachments of bacteria by either exhibiting an antibiofouling affect or by inactivating any cells coming into contact with the surface. Antibacterial surfaces can be divided in two groups: (i) antibiofouling surfaces that may resist or prevent cellular attachment due to the presence of an unfavorable surface topography or surface chemistry, and (ii) 
bactericidal surfaces that disrupt the cell on contact, causing cell death. The CS process has also emerged as a promising process to functionalize surfaces in such way.

The use of inorganic antimicrobial agents has attracted interest for its improved safety and stability verse organic antimicrobial agents. There has been a great development during recent years in antibacterial coatings but they are not still clinically much used; however, more developments and investigations are being explored to achieve both, excellent tissue integration ability and good antibacterial properties [153]. Silver (Ag) has already been highlighted as an antibacterial material. The combination of bioactivity (HA) and antibacterial properties (Ag) have been previously reported and the results indicated that the antibacterial activity increased with increasing HA-Ag nanopowder concentrations [144]. Alternatively, ceramic powder of zinc oxide ( $\mathrm{ZnO})$, calcium oxide $(\mathrm{CaO})$ and magnesium oxide $(\mathrm{MgO})$ have found antibacterial activity. Combinations of $\mathrm{ZnO} / \mathrm{Ti}$ powders with different ratios have been performed to produce composite coated implants [154]; the results show that the viability of cells on $\mathrm{ZnO} 20 / \mathrm{Ti} 80$ was higher than on $\mathrm{ZnO50/Ti50}$ and $\mathrm{ZnO} 0$ /Ti20 samples, thus proving that the cell viability decreased with increasing $\mathrm{ZnO}$ concentration in the coating composition. On the other hand, the bactericidal effect of $\mathrm{TiO}_{2}$ coatings has also been extensively studied; specifically, CS anatase coatings were investigated by Kliemann et al. [123]. A kill rate of $99.99 \%$ was obtained after 5 min of expositng the bacteria Pseudomonas Aeruginosa to UV light with a peak intensity of $360 \mathrm{~nm}$. Certain stagnation of the decay of the bacteria was foind, which could be attributed to non-coated areas present due to the impossibility of covering all the surface of the substrate by means of anchoring $\mathrm{TiO}_{2}$ particles. Other coatings that are committed to antibacterial properties thank to $\mathrm{ZnO}$ are made of Novaron VZ 600 (a commercial available inorganic antimicrobial powder made from glass, with the functional material being $\mathrm{ZnO}$ ) onto $\mathrm{Ti}$ [155]. Those studies were developed to analyze the differences among surfaces using different processing pressures and analysis of the antimicrobial with CS due to the low heat powder resistance. Results have shown that S.Areus cells on samples decreased after $24 \mathrm{~h}$ culture, even on non-coated plates. Two possibilities were reported (i) Roughness can contribute to antimicrobial ability and (ii) medium concentration may have been too low for this bacterium.

Moreover, antibacterial coatings not only focus on orthopedic and implant applications, but also in touch surfaces where there is certain risk of infection. Metals like copper 
$(\mathrm{Cu})$ have been employed for this purpose. In the case of copper, its antibacterial activity not only comes from itself but also the utilized technique. The specific mechanism by which copper affects cellular structures is not yet proven, but the active agent of cell destruction is generally consider to be the copper ion [156]. As the fact that CS deals with high particle velocities leading to extreme work hardening and high dislocation density within the deposit, causes an increase of ion diffusion through the grain dislocations leading to microbial destruction [156]. Champagne et al. [156] produced copper surfaces onto aluminum using three thermal spray methods: plasma spray, wire spray and cold spray, in order to analyze the microbiologic differences and decrease the risk of infection of bacterial contamination on touch surfaces such a hospital table. CS produced the minimum percentage of MRSA (Meticikllin-Resistant Staphylococcus Aureus) due to the high number of dislocations within the coating.

Other attempts of antibacterial coatings were realized mixed with aluminum power (Al). The use of aluminum is cause for a number of cosmetic used, repair, corrosion and protection applications, also for its low density that could be accelerated to very high velocities in $\mathrm{CS}$ and the available commercially variety of composition of Al powders. Table 7 summarizes the CS spraying conditions used for the antibacterial coatings referenced within this section.

\section{Summary}

All the above coating systems try to satisfy the main requirements for a biocoating, either in biological (biocompatibility and bioactivity), mechanical or antibacterial terms. Terms like "structural design" and "deposition techniques" are involved in the development of the fabrication process to obtain cost-efficient products making it commercially reproducible and attainable to all types of markets. From this point of view, it is worth taking into consideration the valuable advantages that $\mathrm{CS}$ has to offer of non-microstructural changes from feedstock powder, high deposition efficiency, low temperature rates and overcoat the wide range of materials that could be applied. Day by day constant work and research demonstrate $\mathrm{CS}$ as a new technique to produce coatings.

However, still a big step has to be overcome in order to translate the experimental studies to the real market. More studies in vitro and in vivo from CS technique are 
required and the addition of antibacterial components must be performed as a necessity upturn in human health.

\section{Acknowledgments}

The authors wish to thank the Generalitat de Catalunya for the project 2014 SGR 1558.

\section{Figure captions}

Fig.1. Evolution of biomaterials science and technology

Fig.2. Bioactivity spectrum for various bioceramic implants: (a) relative rate of bioactivity and (b) time dependence of formation of bone bonding at an implant interface [(A) 45S5 Bioglass ${ }^{\circledR}$, (B) Mina13 Ceravital ${ }^{\circledR}$, (C) 55S4.3 Bioglass ${ }^{\circledR}$, (D) A/W glass-ceramic, (E)HA, (F) KGy213 Ceravital $\left.{ }^{\circledR}\right]$ [6]

Fig.3. Variables and stages of coating formation in conventional thermal spray processes

Fig.4 Schema of TS techniques according to energy source

Fig.5. Schema of CS technique

Fig.6. Stages of coating formation in the cold spray process [97]

Fig.7. Porous Ti coatings by CS from less to high energetic conditions (a-d) [122]

Fig.8. Porous Ti coatings (a) SEM free surface image and (b) MO Cross section image [126], (c) SEM free surface image (d) SEM cross section image[127]

Fig.9. In vivo evaluation of bare PEEK and HA-PEEK at 4 weeks (a) and 8 weeks (b) [141]

\section{References}

[1]Gaona M. Recubrimientos biocompatibles obtenidos por Proyección Térmica y estudio in vitro de la función osteoblástica. PhD thesis. Universitat de Barcelona, 2007.

[2]Hench LL. Biomaterials: a forecast for the future. Biomater 1998;19:1419-23.

[3]Ratner BD, Hoffman AS, Schoen FJ, Lemons JE. Introduction - Biomaterials Science: An Evolving, Multidisciplinary Endeavor. In: Ratner BD, Hoffman AS, Schoen FJ, Lemons JE, editors. Biomaterials Science, 3rd ed. Academic Press; 2013. 
[4]Ramakrishna S, Mayer J, Wintermantel E, Leong KW. Biomedical applications of polymer-composite materials: a review. Compos Sci Technol 2001;61:1189-224.

[5]William DF. Consensus and definitions in biomaterials. In: de Potter C, de Lange K, de Groot K, Lee AJC, editors. Advances in biomaterials. Amsterdam; Elsevier; 1987 p.11-6.

[6]Cao W, Hench LL. Bioactive materials. Ceram Inter 1996;22:493-507.

[7]Jones J, Clare A. Bio-Glasses: An Introduction. John Wiley \& Sons; 2012.

[8]Kalita S. Nanostructured Biomaterials. In: Seal S, editor. Functional Nanostructures, Springer; 2008.

[9]Bronziono JD. The Biomedical Engineering HandBook Vol 1. 2nd ed. Boca Raton: CRC Press LLC; 2000.

[10]Salinas AJ, Vallet-Regi M. Bioactive ceramics: from bone grafts to tissue engineering. RSC Adv 2013;3:11116-31.

[11]Katti KS. Biomaterials in total joint replacement. Colloid Surf B: Biointerface 2004;39:133-42.

[12]Bauer S, Schmuki P, von der Mark K, Park J. Engineering biocompatible implant surfaces: Part I: Materials and surfaces. Prog Mater Sci 2013;58:261-326.

[13]Khan SP, Auner GG, Newaz GM. Influence of nanoscale surface roughness on neural cell attachment on silicon. Nanomed: Nanotechnol, Biol Med 2005;1:125-9.

[14]Yun H-S, Park J-W, Kim S-H, Kim Y-J, Jang J-H. Effect of the pore structure of bioactive glass balls on biocompatibility in vitro and in vivo. Acta Biomater 2011;7:2651-60.

[15]Singhatanadgit W. Biological Responses to New Advanced Surface Modifications of Endosseous Medical Implants. Bone Tissue Regen Insights 2009;2:1-11.

[16]Lin L, Wang H, Ni M, Rui Y, Cheng T-Y, Cheng C-K. Enhanced osteointegration of medical titanium implant with surface modifications in micro/nanoscale structures. $\mathrm{J}$ Orthop Transl 2014;2:35-42. 
[17]Yang YZ, Tian JM, Tian JT, Chen ZQ, Deng XJ, Zhang DH. Preparation of graded porous titanium coatings on titanium implant materials by plasma spraying. J Biomed Mater Res 2000;52:333-7.

[18]Endres S, Wilke M, Knöll P, Frank H, Kratz M, Wilke A. Correlation of in vitro and in vivo results of vacuum plasma sprayed titanium implants with different surface topography. J Mater Sci: Mater Med 2008;19:1117-1125.

[19]Borsari V, Giavaresi G, Fini M, Torricelli P, Tschon M, Chiesa R. Comparative in vitro study on a ultra-high roughness and dense titanium coating. Biomater 2005;26:4948-55.

[20] Chen Y, Zheng X, Ji H, Ding C. Effect of Ti-OH formation on bioactivity of vacuum plasma sprayed titanium coating after chemical treatment. Surf Coat Technol 2007;202:494-8.

[21]Jaeggi C, Mooser R, Frauchiger V, Wyss P. 3D characterization of open porous vacuum plasma sprayed titanium coatings by means of high resolution micro computer tomography. Mater Lett 2009;63:2643-5.

[22]Kinos T, Chen SL, Siitonen P, Kettunen P. Densification of plasma-sprayed titanium and tantalum coatings. JTST 1996;5:439-44.

[23]Stanisic J, Kosikowsky D, Mohanty PS. High temperature Erosion behavior of Thermal Sprayed Tantalum. In: Sudarshan TS, Stiglich JJ, editors. Proceedings of the $19^{\text {th }}$ International Conference on Surface Modification Technologies. ASM International $2005,28-33$

[24]Balla VK, Bodhak S, Bose S, Bandyopadhyay A. Porous tantalum structures for bone implants: Fabrication, mechanical and in vitro biological properties. Acta Biomater 2010;6:3349-59.

[25]Matson DW, Merz MD, McClanahan ED. High rate sputter deposition of wear resistant tantalum coatings. J Va Sci Technol A 1992;10:1791-96

[26]Rai M, Yadav A, Gade A. Silver nanoparticles as a new generation of antimicrobials. Biotechnol Adv 2009;27:76-83. 
[27]Knetsch MLW, Koole LH. New Strategies in the Development of Antimicrobial Coatings: The Example of Increasing Usage of Silver and Silver Nanoparticles. Polym $2011 ; 3: 340-366$.

[28]Melaiye A, Youngs WJ. Silver and its application as an antimicrobial agent. Expert Opin Ther Patents 2005;15:125-30.

[29]Schierholz JM, Lucas LJ, Rump A, Pulverer G. Efficacy of silver-coated medical devices. J Hosp Infect 1998;40:257-62.

[30]Gosheger G, Hardes J, Ahrens H, Streitburger A, Buerger H, Erren M, et al. Silvercoated megaendoprostheses in a rabbit model - an analysis of the infection rate and toxicological side effects. Biomater 2004;25:5547-56.

[31]Tobin EJ, Bambauer R. Silver Coating of Dialysis Catheters to Reduce Bacterial Colonization and Infection. Therapeutic Apher Dial 2003;7:504-9.

[32]Gray JE, Norton PR, Alnouno R, Marolda CL, Valvano MA, Griffiths K. Biological efficacy of electroless-deposited silver on plasma activated polyurethane. Biomater 2003;24:2759-65.

[33]Dowling DP, Donnelly K, McConnell ML, Eloy R, Arnaud MN. Deposition of antibacterial silver coatings on polymeric substrates. Thin Solid Films 2001;398-399:6026.

[34]Bosetti M, Massè A, Tobin E, Cannas M. Silver coated materials for external fixation devices: in vitro biocompatibility and genotoxicity. Biomater 2002;23:887-92.

[35]Noda I, Miyaji F, Ando Y, Miyamoto H, Shimazaki T, Yonekura Y, et al. Development of novel thermal sprayed antibacterial coating and evaluation of release properties of silver ions. J Biomed Mater Res Part B: Appl Biomater 2009;89B:456-65.

[36]Ando Y, Miyamoto H, Noda I, Sakurai N, Akiyama T, Yonekura Y, et al. Calcium phosphate coating containing silver shows high antibacterial activity and low cytotoxicity and inhibits bacterial adhesion. Mater Sci Eng: C 2010;30:175-80.

[37]Miola M, Ferraris S, Di Nunzio S, Robotti PF, Bianchi G, Fucale G, et al. Surface silver-doping of biocompatible glasses to induce antibacterial properties. Part II: plasma sprayed glass-coatings. J Mater Sci: Mater Med 2009;20:741-9. 
[38]Li B, Liu X, Meng F, Chang J, Ding C. Preparation and antibacterial properties of plasma sprayed nano-titania/silver coatings. Mater Chem Phys 2009;118:99-104.

[39]Li B, Liu X, Cao C, Meng F, Dong Y, Cui T, et al. Preparation and antibacterial effect of plasma sprayed wollastonite coatings loading silver. Appl Surf Sci $2008 ; 255: 452-4$.

[40]Zheng X, Chen Y, Xie Y, Ji H, Huang L, Ding C. Antibacterial Property and Biocompatibility of Plasma Sprayed Hydroxyapatite/Silver Composite Coatings. J Therm Spray Technol 2009;18:463-463.

[41]Fernández J, Gaona M, Guilemany JM. Tribological Study of Plasma Hydroxyapatite Coatings. Key Eng Mater 2004;254-256:383-86

[42]Heimann RB, Vu TA. Low-pressure plasma-sprayed (LPPS) bioceramic coatings with improved adhesion strength and resorption resistance. J Therm Spray Technol 1997;6:145-9.

[43]Sun L, Berndt CC, Gross KA, Kucuk A. Material fundamentals and clinical performance of plasma-sprayed hydroxyapatite coatings: A review. J Biomed Mater Res 2001;58:570-92.

[44]Tsui YC, Doyle C, Clyne TW. Plasma sprayed hydroxyapatite coatings on titanium substrates Part 1: Mech Prop Residual Stress Lev. Biomater 1998;19:2015-29.

[45]Fernández J, Gaona M, Guilemany JM. Effect of Heat Treatments on HVOF Hydroxyapatite Coatings. J Therm Spray Tech 2007;16:220-8.

[46]Lima RS, Khor KA, Li H, Cheang P, Marple BR. HVOF spraying of nanostructured hydroxyapatite for biomedical applications. Mater Sci Eng: A 2005;396:181-7.

[47]Khor K., Li H, Cheang P. Processing-microstructure-property relations in HVOF sprayed calcium phosphate based bioceramic coatings. Biomater 2003;24:2233-43.

[48]Cho JS, Kang YC. Nano-sized hydroxyapatite powders prepared by flame spray pyrolysis. J Alloys and Compd 2008;464:282-7. 
[49]Melero H. Recubrimientos biocompatibles de Hidroxiapatita-Titania obtenidos mediante Proyección Térmica de Alta Velocidad (HVOF). PhD thesis. Universitat de Barcelona, 2014.

[50]Pajares López M, Hernández Cortés P, Peregrinaf Palomares M, Hernández Hernández MA. Vástagos cementados y no cementados en artroplastias totales de cadera por coxopatías mecánicas. Rev Esp Cir Osteoartic 1998;33:59-65.

[51]Chern Lin JH, Liu ML, Ju CP. Structure and properties of hydroxyapatite-bioactive glass composites plasma sprayed on Ti6Al4V. J Mater Sci: Mater Med 1994;5:279-83.

[52]Wheeler DL, Montfort MJ, McLoughlin SW. Differential healing response of bone adjacent to porous implants coated with hydroxyapatite and 45S5 bioactive glass. J Biomed Mater Res 2001;55:603-12.

[53] Floroian L, Popescu A, Servan N, Mihailescu Ion N. Polymer-Bioglass Composite Coatings: A Promising Alternative for Advanced Biomedical Implants. http://cdn.intechopen.com/pdfs-wm/16716.pdf

[54]Cai F, Miyata C, Huang X, Yang Q. Microstructure, bioactivity and wear resistance of sintered composite $\mathrm{Co}-\mathrm{Cr}-\mathrm{Mo} / \operatorname{Bioglass}((\mathrm{R}))$ for medical implant applications. Int $\mathbf{J}$ Surf Sci Eng 2014;8:264-81.

[55]Pourhashem S, Afshar A. Double layer bioglass-silica coatings on 316L stainless steel by sol-gel method. Ceram Int 2014;40:993-1000.

[56]Ananth KP, Suganya S, Mangalaraj D, Ferreira JMF, Balamurugan A. Electrophoretic bilayer deposition of zirconia and reinforced bioglass system on Ti6Al4V for implant applications: An in vitro investigation. Mater Sci Eng C-Mater Biol Appl 2013;33:4160-6.

[57]Wang DG, Chen CZ, Jin QP, Li HC, Pan YK. HA/Bioglass composite films deposited by pulsed laser with different substrate temperature. Appl Phys A-Mater Sci Process 2014;114:897-902.

[58]Sun L, Berndt CC, Khor KA, Cheang HN, Karlis A. Gross, Surface characteristics and dissolution behavior of plasma-sprayed hydroxyapatite coating. J Biomed Mater Res 2002; 62:228-236 
[59]Formin AA, Steinhauer AB, Lyasnikov VN, Wenig SB, Zakharevich AM. Nanocrystalline structure of the surface layer of plasma-sprayed hydroxyapatite coatings obtained upon preliminary induction heat treatment of metal base. Tech Phys Lett $2012 ; 38: 481-483$

[60]Kurzweg H, Heimann RB, Troczynski T, Wayman ML. Development of plasmasprayed bioceramic coatings with bond coats based on titania and zirconia. Biomater 1998;19:1507-11.

[61]F1609-08 Standard Specification for calcium phosphate Coatings for Implantable Materials

[62]ISO Standard 13779-1:2008 Implants for surgery - Hydroxyapatite - Part 1: Ceramic hydroxyapatite

[63]ISO Standard 13779-1:2008 Implants for surgery - Hydroxyapatite - Part 2: Coatings of hydroxyapatite

[64]ISO Standard 13779-1:2008 Implants for surgery - Hydroxyapatite - Part 3: Chemical analysis and chartacterization of crystallinity and phase purity

[65]ASTM F 2068-00 Standard Specification for Femoral Prostheses - Metallic Implants.

[66]Mohseni E, Zalnezhad E, Bushroa AR. Comparative investigation on the adhesion of hydroxyapatite coating on $\mathrm{Ti}-6 \mathrm{Al}-4 \mathrm{~V}$ implant: A review paper. Int $\mathrm{J}$ Adhes and Adhes 2014;48:238-57.

[67]Kuo MC, Yen SK. The process of electrochemical deposited hydroxyapatite coatings on biomedical titanium at room temperature. Mater Sci Eng: C 2002;20:15360 .

[68]Yoshimura M, Byrappa K. Hydrothermal processing of materials: past, present and future. J Mater Sci 2008;43:2085-103.

[69]Darr JA, Guo ZX, Raman V, Bououdina M, Rehman IU. Metal organic chemical vapour deposition (MOCVD) of bone mineral like carbonated hydroxyapatite coatings. Chem Commun 2004:696-7. 
[70]Li H, Khor KA, Cheang P. Titanium dioxide reinforced hydroxyapatite coatings deposited by high velocity oxy-fuel (HVOF) spray. Biomater 2002;23:85-91.

[71]Melero H, Fargas G, Garcia-Giralt N, Fernández J, Guilemany JM. Mechanical performance of bioceramic coatings obtained by high-velocity oxy-fuel spray for biomedical purposes. Surf Coat Technol 2014;242:92-9.

[72]Melero H, Torrell M, Fernández J, Gomes JR, Guilemany JM. Tribological characterization of biocompatible $\mathrm{HAp}-\mathrm{TiO}_{2}$ coatings obtained by high velocity oxyfuel spray. Wear 2013;305:8-13.

[73]Bhadang KA, Gross KA. Influence of fluorapatite on the properties of thermally sprayed hydroxyapatite coatings. Biomater 2004;25:4935-45.

[74]Gu YW, Khor KA, Pan D, Cheang P. Activity of plasma sprayed yttria stabilized zirconia reinforced hydroxyapatite/ $\mathrm{Ti}-6 \mathrm{Al}-4 \mathrm{~V}$ composite coatings in simulated body fluid. Biomater 2004;25:3177-85.

[75]Fathi MH, Azam F. Novel hydroxyapatite/tantalum surface coating for metallic dental implant. Mater Lett 2007;61:1238-41.

[76]Roy M, Fielding GA, Beyenal H, Bandyopadhyay A, Bose S. Mechanical, In vitro Antimicrobial, and Biological Properties of Plasma-Sprayed Silver-Doped Hydroxyapatite Coating. ACS Appl Mater Interfaces 2012;4:1341-9.

[77]Yonekura Y, Miyamoto H, Shimazaki T, Ando Y, Noda I, Mawatari M, et al. Osteoconductivity of thermal-sprayed silver-containing hydroxyapatite coating in the rat tibia. J Bone Jt Surg 2011;93-B:644-9.

[78]Shimazaki T, Miyamoto H, Ando Y, Noda I, Yonekura Y, Kawano S, et al. In vivo antibacterial and silver-releasing properties of novel thermal sprayed silver-containing hydroxyapatite coating. J of Biomed Mater Res Part B: Appl Biomater 2010;92B:3869.

[79]Balani K, Anderson R, Laha T, Andara M, Tercero J, Crumpler E, et al. Plasmasprayed carbon nanotube reinforced hydroxyapatite coatings and their interaction with human osteoblasts in vitro. Biomater 2007;28:618-24. 
[80]Green SM, Schlegel J. A polyaryletherketone biomaterial for use in medical implant applications. Polym for the Med Ind Proc, Brussels, 14th-15th May 2001:1-7

[81]Li H, Zou X, Woo C, Ding M, Lind M, Bünger C. Experimental lumbar spine fusion with novel tantalum-coated carbon fiber implant. J of Biomed Mater Res Part B: Appl Biomater 2007;81B:194-200.

[82]Ma R, Tang T. Current Strategies to Improve the Bioactivity of PEEK. Int J Mol Sci. $2014 ; 15: 5426-5445$.

[83]Roeder RK, Conrad TL. Bioactive Polyaryletherketone Composites. In: Kurtz SM, editor. PEEK Biomaterials Handbook, Oxford: William Andrew Publishing; 2012, p. $163-79$.

[84]Riner M, Roth A, Brandsberg F, Wintermantel E, Mayer J. Development of a human hip endoprosthesis stem made by injection molding of carbon fiber reinforced PEEK. http://www.iccmcentral.org/Proceedings/ICCM13proceedings/SITE/PAPERS/paper-1409.pdf

[85]Brydone AS, Meek D, Maclaine S. Bone grafting, orthopaedic biomaterials, and the clinical need for bone engineering. Proceedings of the Institution of Mechanical Engineers, Part H: J of Eng in Med 2010;224:1329-43.

[86]Furlong R, Osborn J. Fixation of hip prostheses by hydroxyapatite ceramic coatings. J Bone Jt Surg, 1991;73-B:741-5.

[87]Jaffe W, Scott D. Total Hip Arthroplasty with Hydroxyapatite-Coated Prostheses. In: Imura S, Wada M, Omori H, editors. Jt Arthroplast, Springer Japan; 1999, 159-87.

[88]Pramanik S, Agarwak AK, Rai KN. Chronology of Total Hip Joint Replacement and Materials Development. Trends Biomater. Artif. Organs 2005; 19:15-26

[89]Cross MJ, Parish EN. A hydroxyapaite-coated total knee replacement. J Bone Jt Surg Br 2005;87B:1073-76

[90]Manley MTC, William N. D’Aantonio, James A. Edin, Avram A. GEESINK, RUDOLPH G. T. Fixation of Acetabular Cups without Cement in Total Hip Arthroplasty. A Comparison of Three Different Implant Surfaces at a Minimum Duration of Follow-up of Five Years*. J Bone Jt Surg 1998;80:1175-85. 
[91]Nilsson KG, Kärrholm J, Carlsson L, Dalén T. Hydroxyapatite coating versus cemented fixation of the tibial component in total knee arthroplasty: Prospective randomized comparison of hydroxyapatite-coated and cemented tibial components with 5-year follow-up using radiostereometry. J Arthroplast 1999;14:9-20.

[92]Zhang S. Biological and Biomedical Coatings Handbook Vol 2. Boca Raton: Taylor \& Francis, 2011.

[93]Davis JR. Introduction to Thermal Spray Processing. In: Davis JR,editors. Handbook of Thermal Spray Technology, ASM International; 2004, p.3-13

[94]Davis JR. Thermal Spray Procesess. In: Davis JR,editors. Handbook of Thermal Spray Technology, ASM International; 2004, p.54-76

[95]Fernández J, Guilemany JM, Gaona M. La proyección térmica en la obtención de recubrimientos biocompatibles: ventajas de la proyección térmica por alta velocidad (HVOF) sobre la proyección térmica por plasma atmosférico (APS). Biomec. 2005;13:16-39.

[96]Kang AS, Singh G, Chawla V. Some Problems Associated with Thermal Sprayed Ha Coatings: A Review. Inter J Surface Engineering Materials. Surf Eng Mater Technol, 2013;3:10-20

[97]Villa M, Dosta S, Fernández J, Guilemany JM. La proyección fría (CGS): Una alternativa a las tecnologías convencionales de deposición. Rev Metal 2012;48:175-91.

[98]Champagne, Victor K. The Cold Spray Materials Deposition Process: Fundamentals and Applications. Cambridge: Woodhead , 2007.

[99]Ghelichi R, Guagliano M. Coating by the Cold Spray Process: a state o the art. Fratt Integr Strutt 2009;8:30-44.

[100]Singh HR, Sidhu TS, Kalsi SBS. Cold spray technology: future of coating deposition processes. Frat Integr Strutt 2012;22:69-84.

[101]Morgan R, Fox P, Pattison J, Sutcliffe C, O’Neill W. Analysis of cold gas dynamically sprayed aluminium deposits. Mater Lett 2004;58:1317-20. 
[102]Suhonen T, Varis T, Dosta S, Torrell M, Guilemany JM. Residual stress development in cold sprayed Al, Cu and Ti coatings. Acta Mater;2013;61:6329-37.

[103]Champagne VK, Helfritch DJ. Mainstreaming cold spray - push for applications. Surf Eng 2014;30:396-403.

[104]Moridi A, Hassani-Gangaraj SM, Guagliano M, Dao M. Cold spray coating: review of material systems and future perspectives. Surf Eng 2014;30:369-95.

[105] Richer, P., et al. Effect of particle geometry and substrate preparation in cold spray. ITSC 2005 “Thermal Spray connects: Explore its surfacing potential!” Basel, Switzerland, 2005, pp.193-199

[106] Makinen H, Langeborn J, Vuoristo P, Adhesion of Cold Sprayed coatings: effect of powder, substrate and heat treatment, Thermal Spray Global Solutions, B. R. Marple, M. M. Hyland, Y. Lau, C. Li, R. S. Lima, G. Montavon Eds. (2007) ASM International pp. 31-36.

[107]Sakaki K, Tajima K, Li H, Shinkai S, Shimitzu Y, Influence of substrate conditions and traverse speed on cold sprayed coatings, International Thermal Spray Conference 2004: Advances in Technology and Application, Osaka (Japan), ASM International, pp.358-362

[108]Wu J, Yang J, Fang H, Yoon S, Lee C. The bond strength of Al-Si coating on mild steel by kinetic spraying deposition. Appl Surf Sci 2006;252:7809-14.

[109]Marrocco T, McCartney DG, Shipway PH, Sturgeon AJ. Production of titanium deposits by cold-gas dynamic spray: Numerical modeling and experimental characterization. J Therm Spray Tech 2006;15:263-72.

[110] Price TS, Shipway PH, McCartney DG. Effect of cold spray deposition of a titanium coating on fatigue behavior of a titanium alloy. J Therm Spray Tech 2006;15:507-12. doi:10.1361/105996306X147108.

[111] Paul D. Eason, A Structure Property Processing Comparison of Cold rolled PM Copper and Cold Gas Dynamically Sprayed Copper. J Powder Metall Min 2012, 1: 101

[112]Miguel JM, Vizcaíno S, Dosta S, Cinca N, Lorenzana C, Guilemany, JM. Recubrimientos de materiales compuestos metal-cerámico obtenidos por nuevas 
tecnologías de proyección térmica: Proyección fría (CGS) y su resistencia al desgaste. Rev Metal n.d.;47:390-401.

[113]Li W-Y, Zhang C, Guo X, Xu J, Li C-J, Liao H, et al. Ti and Ti-6Al-4V Coatings by Cold Spraying and Microstructure Modification by Heat Treatment. Adv Eng Mater 2007;9:418-23.

[114] Wong W, Rezaeian A, Yue S, Irissou E, Legoux J-G, Effect of Gas Temperature, Gas Pressure, and Particle Characteristics on Cold Sprayed Pure Titanium Coatings, Thermal Spray 2009: Proceedings of the International Thermal Spray Conference, B.R. Marple, M.M. Hyland, Y.-C. Lau, C.-J. Li, R.S. Lima, G. Montavon, ASM International (2009), p 231-236

[115] Li C-J, Li W-Y. Deposition characteristics of titanium coating in cold spraying. Surface and Coatings Technology 2003;167:278-83. doi:10.1016/S02578972(02)00919-2.

[116]Sun J, Han Y, Cui K. Innovative fabrication of porous titanium coating on titanium by cold spraying and vacuum sintering. Mater Lett 2008;62:3623-5.

[117] Qiu D, Zhang M, Grøndahl L. A novel composite porous coating approach for bioactive titanium-based orthopedic implants. J Biomed Mater Res Part A 2013;101A:862-72.

[118]Gardon M, Latorre A, Torrell M, Dosta S, Fernández J, Guilemany JM. Cold gas spray titanium coatings onto a biocompatible polymer. Mater Lett 2013;106:97-9.

[119]J.M.Guilemany, S.Dosta, N.Cinca, J.Fernández, I.Garcia, Feasibility of cold gas spraying to produce metal coatings onto activaated polymeric substrates. Thermal Spray Centre (CPT). Intellectual properties protection (iPP). Ref.1240B p.10

[120]AL-Mangour B, Mongrain R, Irissou E, Yue S. Improving the strength and corrosion resistance of 316L stainless steel for biomedical applications using cold spray. Surf Coat Technol 2013;216:297-307.

[121]Steenkiste T, Gorkiewicz DW. Analysis of tantalum coatings produced by the kinetic spray process. J Therm Spray Technol 2004;13:265-73. 
[122]Lozier A., Popoola O. O., Mason J. J., Forstein M.. Bone fracture fixation system. US Patent 0198286 A1, August 6,2009.

[123] Kliemann J-O, Gutzmann H, Gaertner F, Huebner H, Borchers C, Klassen T. Formation of Cold-Sprayed Ceramic Titanium Dioxide Layers on Metal Surfaces. J Therm Spray Technol 2011;20:292-8.

[124]Salim NT, Yamada M, Nakano H, Fukumoto M. The Synthesis of Titanium Dioxide $\left(\mathrm{TiO}_{2}\right)$ Powder for Cold Spray Process. 3rd International Congress on Ceramics (icc): Novel Chemical Processing Sol-Gel and Solution-Based Processing 2011;18:032019. doi:10.1088/1757-899X/18/3/032019.

[125]Ishikawa K, Miyamoto Y, Nagayama M, Asaoka K. Blast coating method: New method of coating titanium surface with hydroxyapatite at room temperature. J Biomed Mater Res 1997;38:129-34.

[126]O'Hare P, Meenan BJ, Burke GA, Byrne G, Dowling D, Hunt JA. Biological responses to hydroxyapatite surfaces deposited via a co-incident microblasting technique. Biomater 2010;31:515-22.

[127]Gbureck U, Masten A, Probst J, Thull R. Tribochemical structuring and coating of implant metal surfaces with titanium oxide and hydroxyapatite layers. Mater Sci Eng: C 2003;23:461-5.

[128]O’Neill L, O’Sullivan C, O’Hare P, Sexton L, Keady F, O’Donoghue J. Deposition of substituted apatites onto titanium surfaces using a novel blasting process. Surf Coat Technol 2009;204:484-8.

[129]O'Sullivan C, O'Hare P, O’Leary ND, Crean AM, Ryan K, Dobson ADW, et al. Deposition of substituted apatites with anticolonizing properties onto titanium surfaces using a novel blasting process. J of Biomed Mater Res Part B: Appl Biomater 2010;95B:141-9.

[130]Byrne GD, O’Neill L, Twomey B, Dowling DP. Comparison between shot peening and abrasive blasting processes as deposition methods for hydroxyapatite coatings onto a titanium alloy. Surf Coat Technol 2013;216:224-31. 
[131] Chun D-M, Ahn S-H. Deposition mechanism of dry sprayed ceramic particles at room temperature using a nano-particle deposition system. Acta Materialia 2011;59:2693-703.

[132] Chun D-M, Choi J-O, Lee CS, Ahn S-H. Effect of stand-off distance for cold gas spraying of fine ceramic particles $(<5 \mu \mathrm{m})$ under low vacuum and room temperature using nano-particle deposition system (NPDS). Surf Coat Technol 2012;206:2125-32.

[133] Akedo J. Aerosol Deposition of Ceramic Thick Films at Room Temperature: Densification Mechanism of Ceramic Layers. Journal of the American Ceramic Society 2006;89:1834-9.

[134]Hahn B-D, Park D-S, Choi J-J, Ryu J, Yoon W-H, Kim K-H, et al. Dense Nanostructured Hydroxyapatite Coating on Titanium by Aerosol Deposition. Journal of the American Ceramic Society 2009;92:683-7. doi:10.1111/j.1551-2916.2008.02876.x.

[135]Park D-S, Kim I-S, Kim H, Chou AHK, Hahn B-D, Li L-H, et al. Improved biocompatibility of hydroxyapatite thin film prepared by aerosol deposition. Journal of Biomedical Materials Research Part B: Applied Biomaterials 2010;94B:353-8. doi:10.1002/jbm.b.31658.

[136]Zhang L, Zhang WT. Numerical investigation on Particle Velocity in Cold Spraying of Hydroxyapatite Coating. Adv Mater Res 2011;18;717-722.

[137]Singh RP. Numerical evaluation, optimization and mathematical validation of cold spraying of hydroxyapatite using taguchi approach. Inter $\mathrm{J}$ Eng Sci Technol 2011;3:7006-15.

[138]Singh RP, Batra B. Effect of Cold Spraying Parameters and their interaction an Hydroxyapatite Deposition. J Appl Fluid Mech 2013;6:555-61

[139]Noorakma AW, Zuhailawati H, Aishvarya V, Dhindaw BK. HydroxyapatiteCoated Magnesium-Based Biodegradable Alloy: Cold Spray Deposition and Simulated Body Fluid Studies. J Mater Eng Perform 2013;22:2997-3004.

[140]Noh JH, Kim DW, An JS, Chang HR, Kim DH, Hong KS, Chin DK. Method for modifying the surface area of a bioinert material. US Patent 0009341 A1, January 12, 2012. 
[141]Lee JH, Jang HL, Lee KM, Baek H-R, Jin K, Hong KS, et al. In vitro and in vivo evaluation of the bioactivity of hydroxyapatite-coated polyetheretherketone biocomposites created by cold spray technology. Acta Biomater 2013;9:6177-87.

[142]Chen MW, McCauley JW, Dandekar DP, Bourne NK. Dynamic plasticity and failure of high-purity alumina under shock loading. Nat Mater 2006;5:614-8.

[143]Mukhopadhyay A, Joshi K, Dey A, Chakraborty R, Rav A, Biswas S, et al. Shock deformation of coarse grain alumina above Hugoniot elastic limit. J Mater Sci 2010;45:3635-51.

[144]Zhou X, Mohanty P. Electrochemical behavior of cold sprayed hydroxyapatite/titanium composite in Hanks' solution. Electrochimica Acta 2012;65:134-40.

[145]Shukla V, Elliott G., Kear B., McCandlish L. Hyperkinetic deposition of nanopowders by supersonic rectangular jet impingement. Scri Mater 2001;44:2179-82.

[146]Zhou X, Hydroxyapatite/Titanium Composite Coating for Biomedical Applications. PhD thesis. University of Michigan, 2012.

[147]Choudhuri A, Mohanty PS, Karthikeyan J. Bio-ceramic Composite Coatings by Cold Spray Technology. Proceedings of the International Thermal Spray Conference 2009:391-96.

[148] Liu Y, Dang Z, Wang Y, Huang J, Li H. Hydroxyapatite/graphene-nanosheet composite coatings deposited by vacuum cold spraying for biomedical applications: Inherited nanostructures and enhanced properties. Carbon 2014;67:250-9.

[149]Sanpo N, Tan M, Cheang P, Khor KA. Antibacterial Property of Cold-Sprayed HA-Ag/PEEK Coating. J Therm Spray Tech 2009;18:10-5.

[150]Gardon M, Melero H, Garcia-Giralt N, Dosta S, Cano IG, Guilemany JM. Enhancing the bioactivity of polymeric implants by means of cold gas spray coatings, Journal of Biomedical Materials Research Part B: Appl Biomater 2014.

[151]Balla VK, Bodhak S, Bose S, Bandyopadhyay A. Porous Tantalum Structures for Bone Implants: Fabrication, Mechanical and In vitro Biological Properties. Acta Biomater 2010; 6: 3349-59. 
[152]Bobyn JD, Stackpool GJ, Hacing SA, Tanzer M, Krygier JJ. Characteristics of bone ingrowth and interface mechanics of a new porous tantalum biomaterial. J Bone Jt Surg Br 1999; 81:907-14

[153]Zhao L, Chu PK, Zhang Y, Wu Z. Antibacterial coatings on titanium implants. J Biomedl Mater Res Part B: Appl Biomater 2009;91B:470-80.

[154]Sanpo N, Hailan C, Loke K, Keng KP, Cheang P, Berndt CC, et al. Biocompatibility and antibacterial property of cold sprayed $\mathrm{ZnO} /$ Titanium composite coating. In: Mendez-Vilas A, Editor. Science and Technology against Microbial Pathogens. Research, Development and Evaluation. Proceedings of the International Conference on Antimicrobial Research, World Scientific; 2010, p.140-44

[155]Tamai K, Kawate K, Kawahara I, Takakura Y, Sakaki K. Inorganic antimicrobial coating for titanium alloy and its effect on bacteria. J Orthop Sci 2009;14:204-9.

[156]Champagne V, Helfritch D. A demonstration of the antimicrobial effectiveness of various copper surfaces. J Biol Eng 2013;7:1-7. 


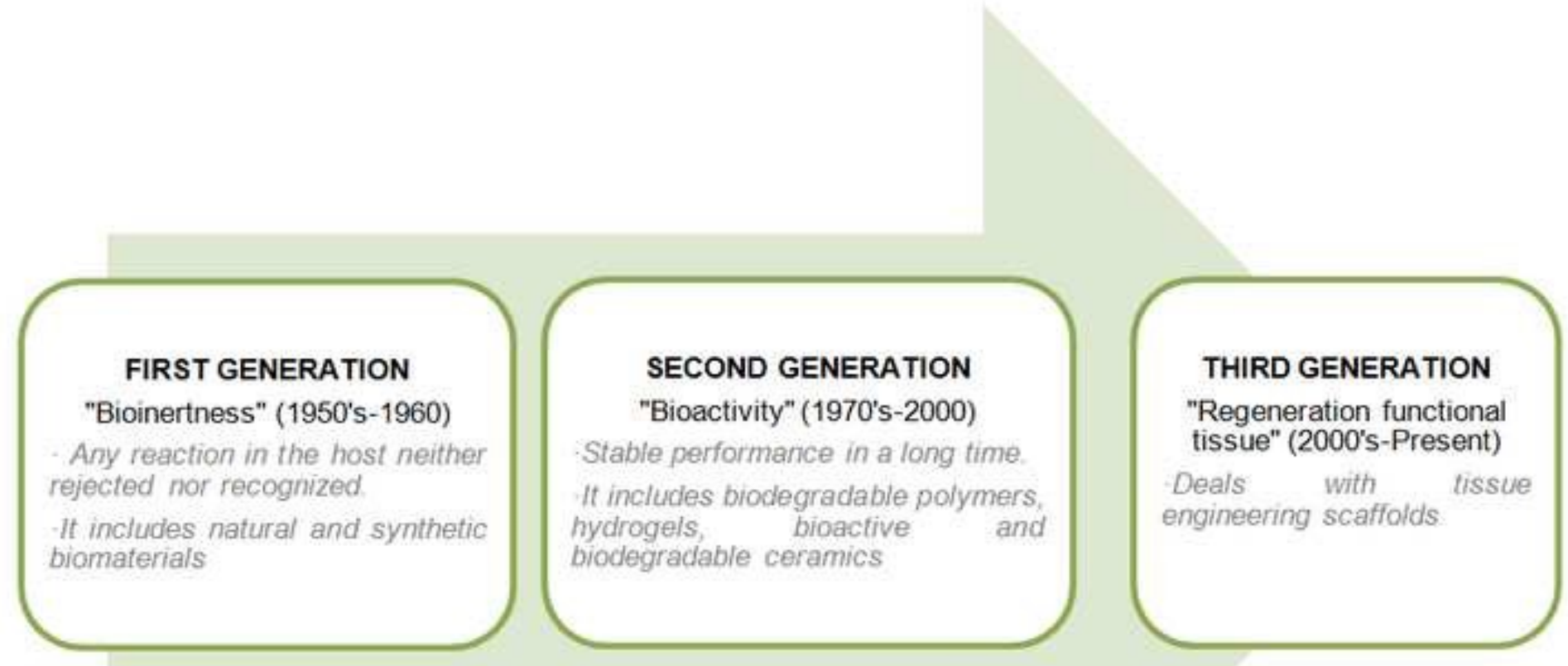




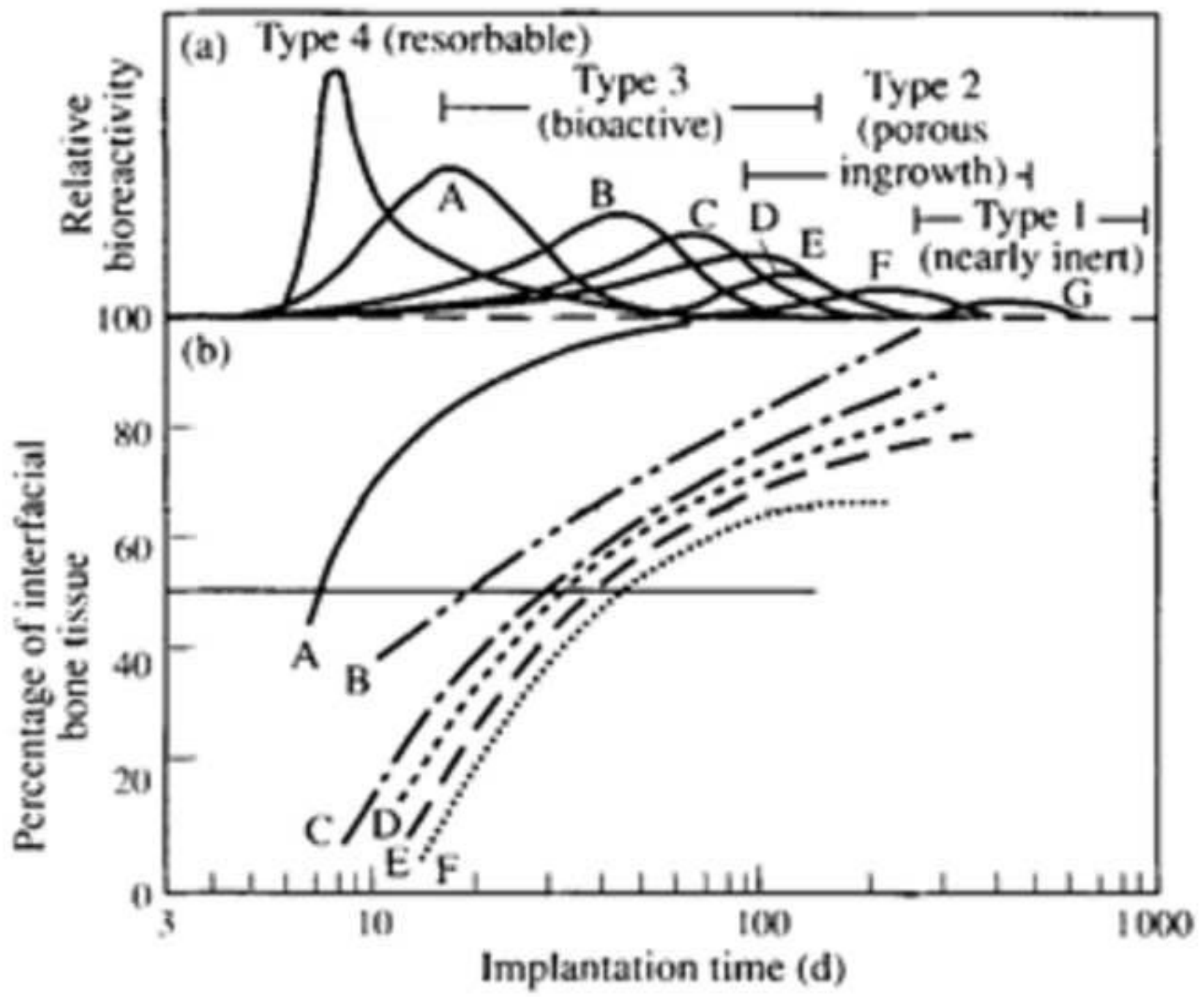




\section{Stages}

1.- Generation of thermal/kinetic energy

2.- Interaction of energy with spray material

3.- Interaction of spray particles with

substrate

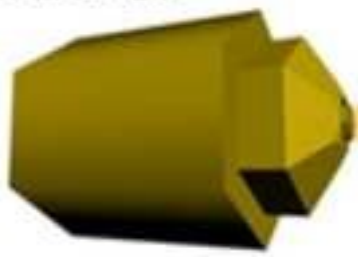

\section{Gun}

Nozzle geometry

Power

Gas flows

Gas compositions
Spray stream

(plasma, flame, etc.)

Composition

Temperature

Velocity

Spray distance

External environment

Turbulence

\section{Substrate}

Surface contamination

Surface profile

Temperature

Chemical and physical properties

Relative speed to gun

\section{Material feed}

Particle size and shape

Feed rate

Injection method and geometry

Carrier gas, flow and velocity

Chemical and physical properties

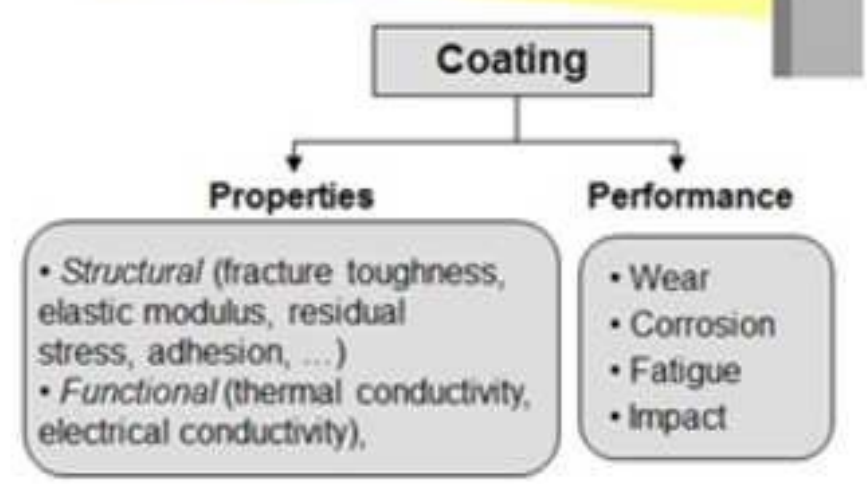




\section{THERMAL SPRAY}

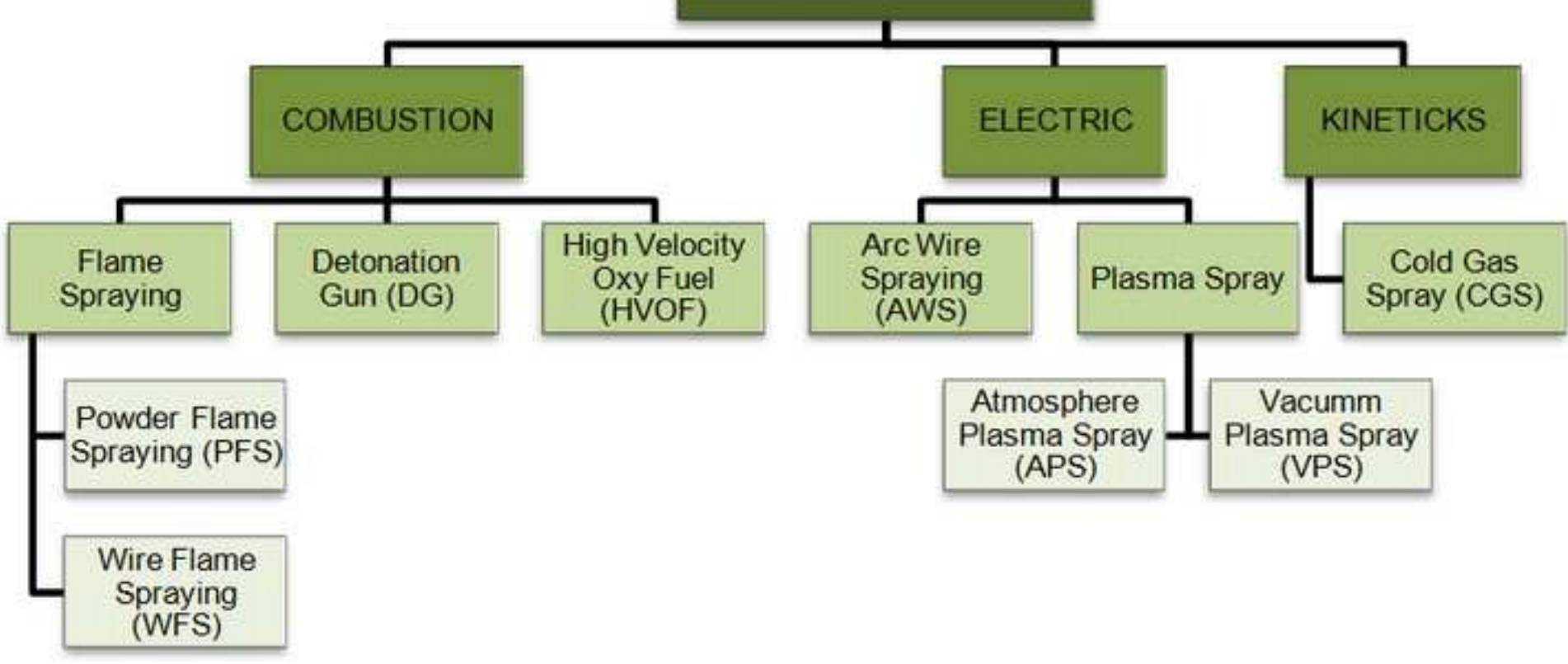


Click here to download Figure: FIG5.tif

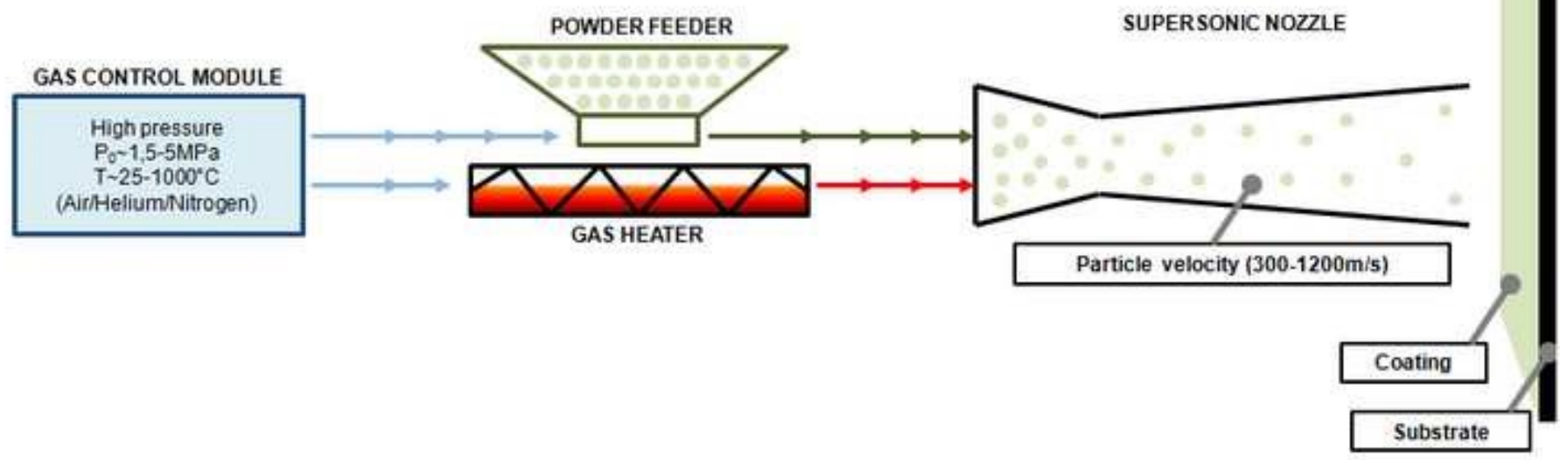


Stage 4: Bulk Deformation

(Cracking, work hardening of particles, removal of

Stage 1: Substrate cratering and first

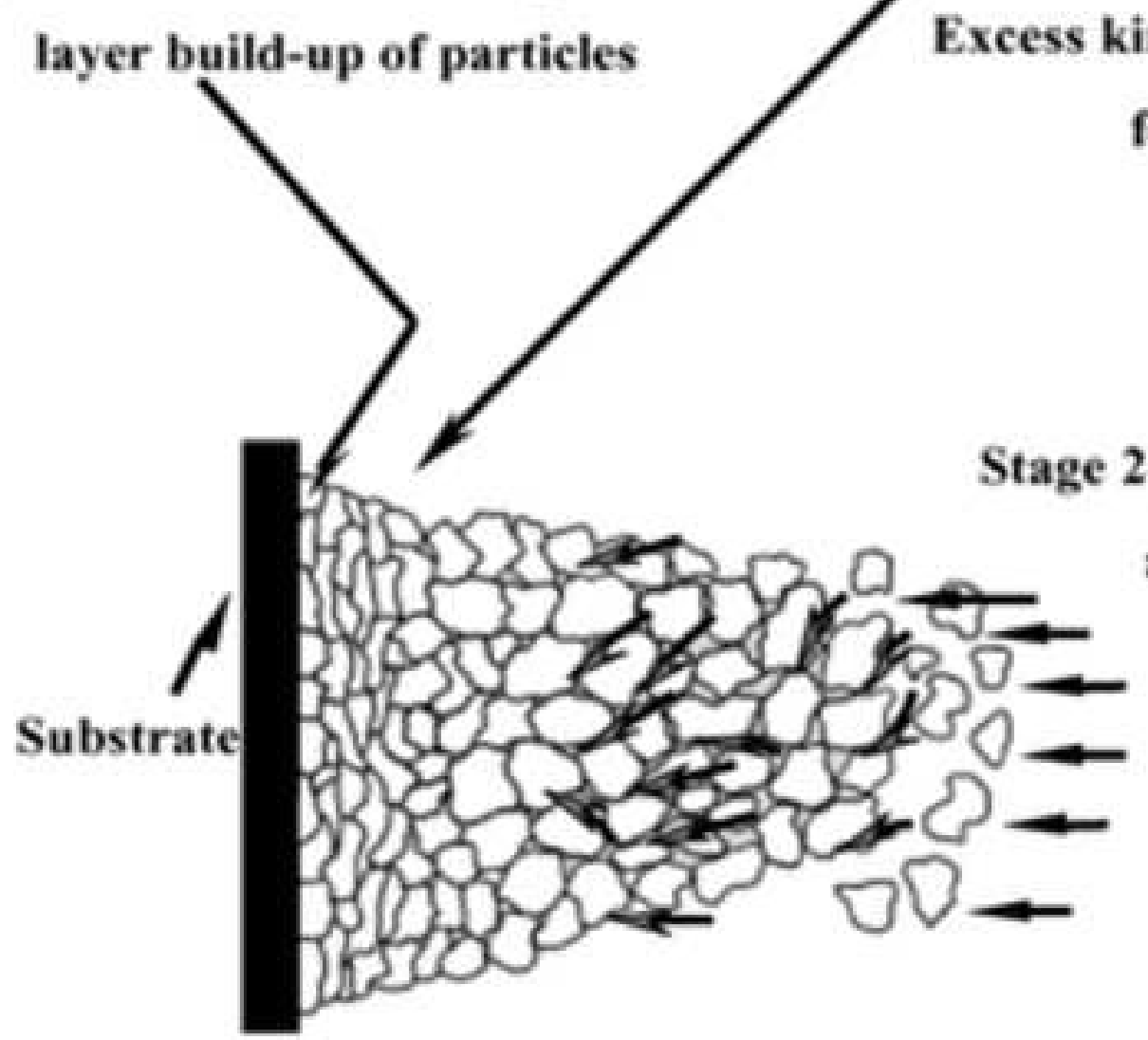
previously bonded particles.)

Excess kinetic energy required for this stage.

Stage 3: Metallurgical bond

formation and void reduction

$\square$ Voids

— Particle rotation $\&$ alignment direction

Particles and realignment 


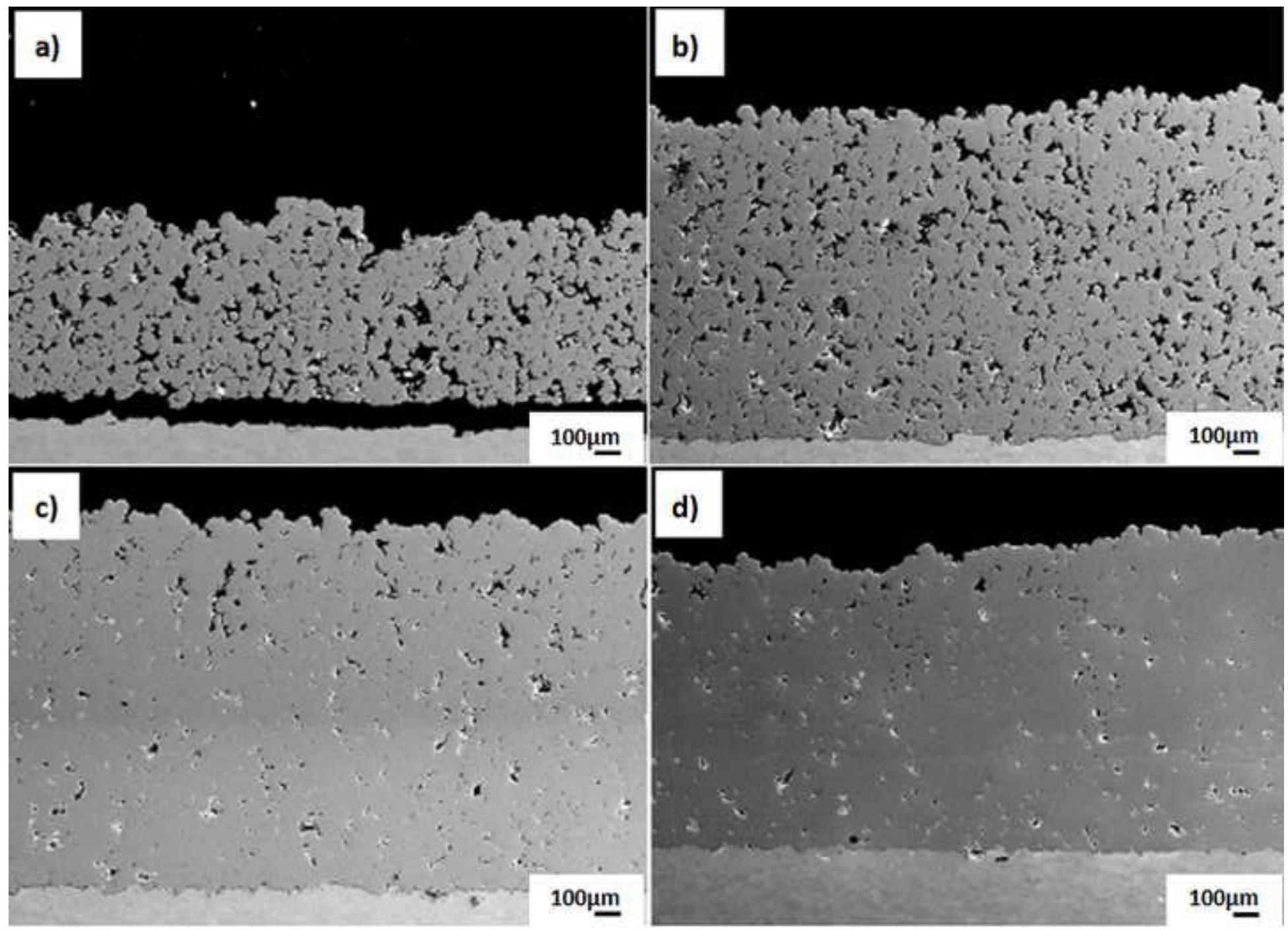




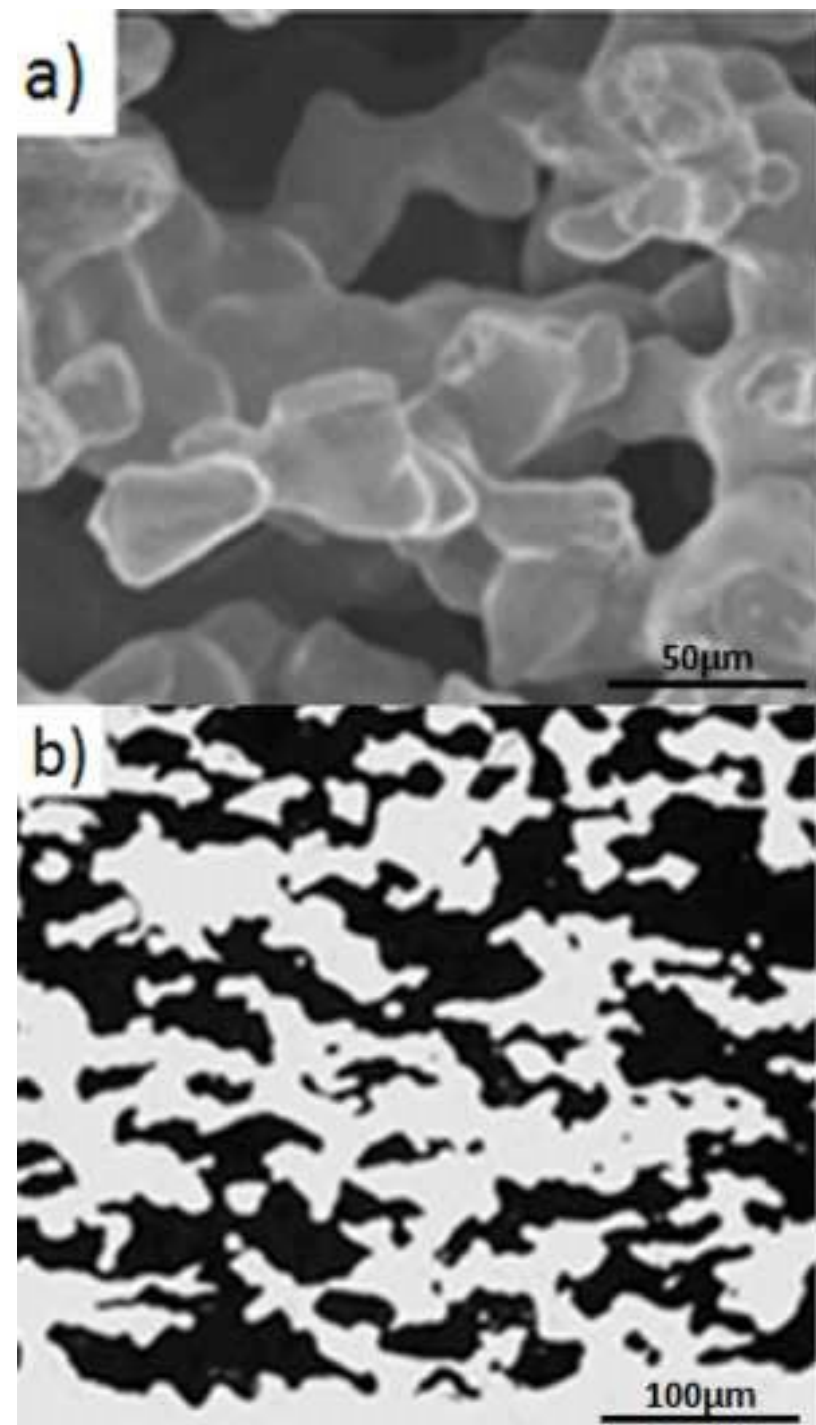

c)
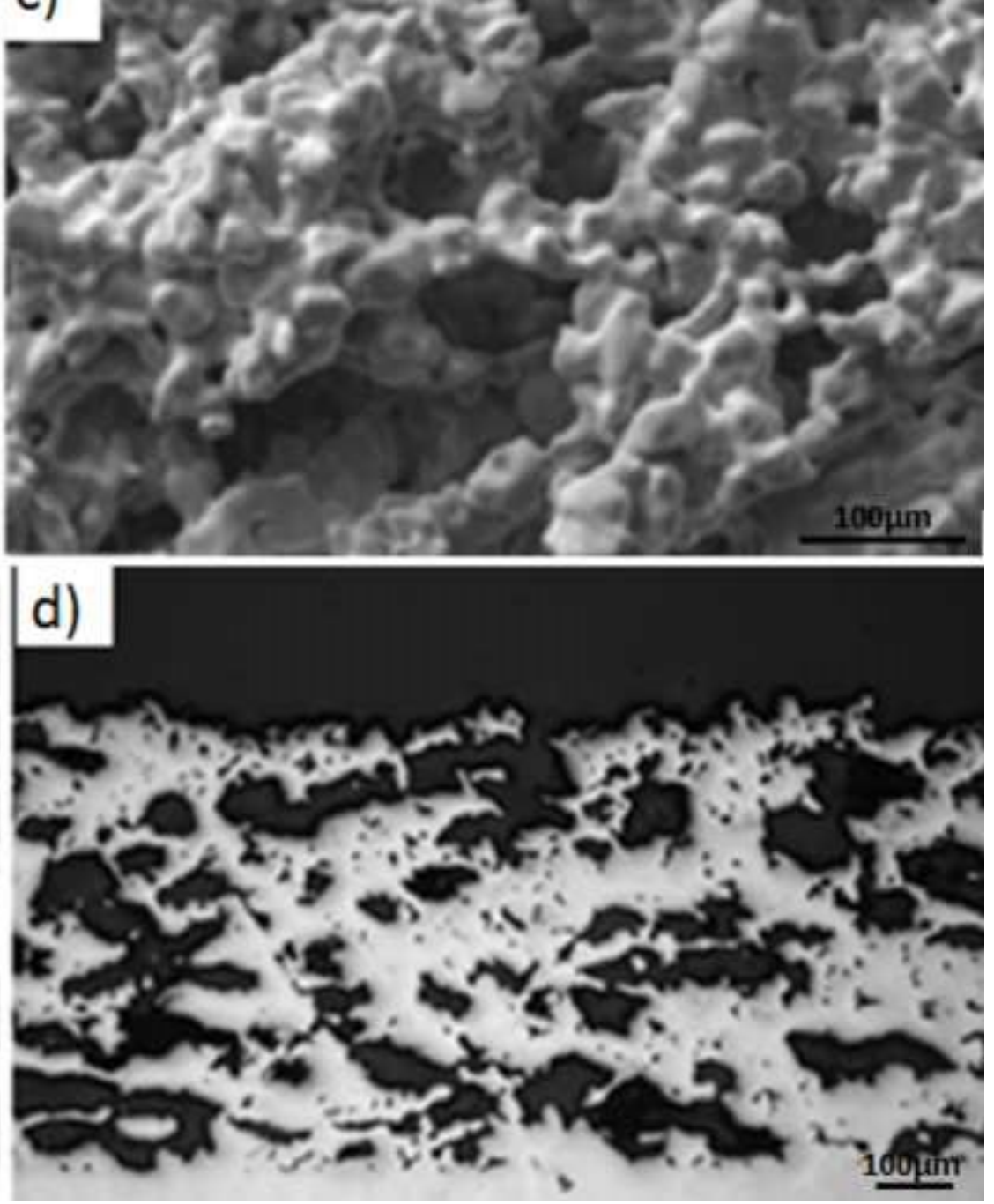
(a)

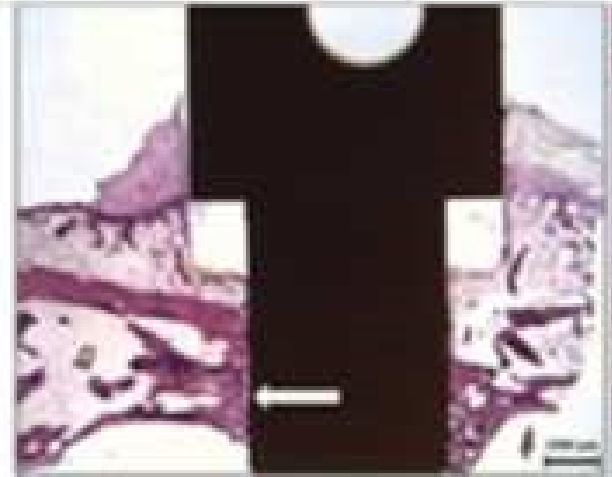

PEEK $4 \mathrm{w} \times 12.5$

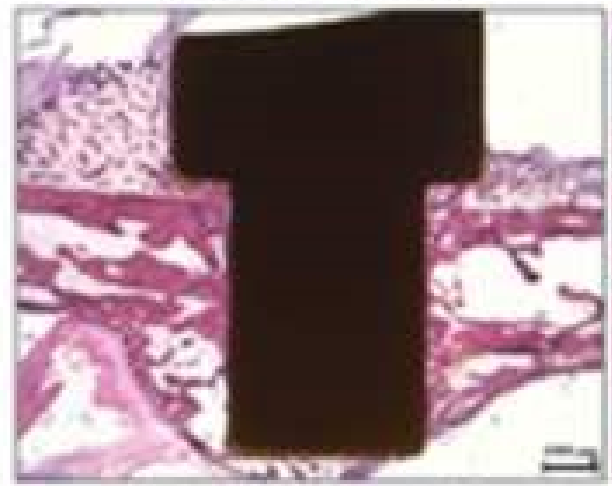

HA-PEEK 4 w $\times 12.5$

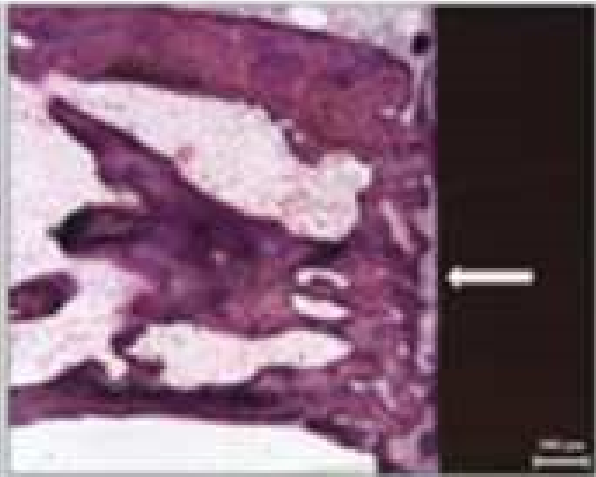

PEEK $4 w \times 40$

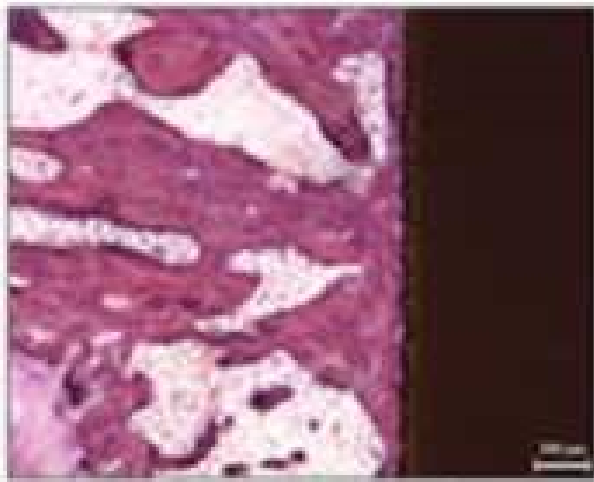

HA-PEEK $4 w \times 40$

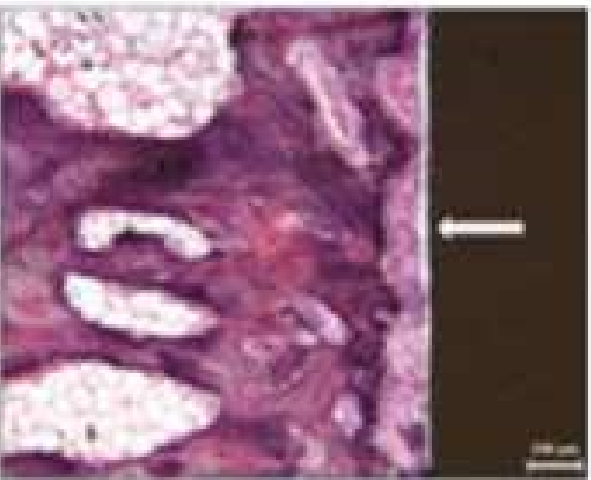

PEEK 4w $\times 100$

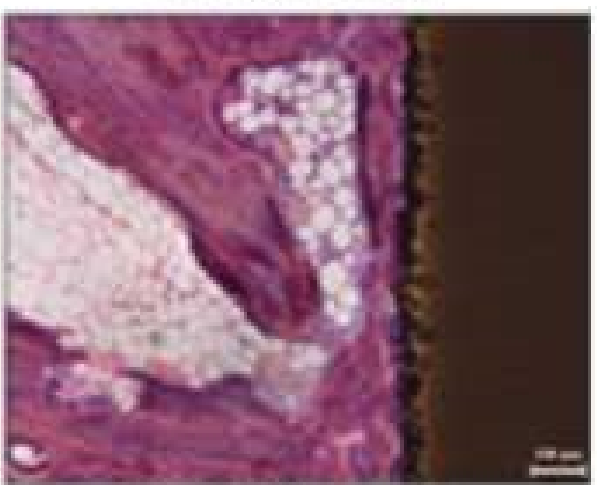

HA-PEEK $4 w \times 100$ (b)

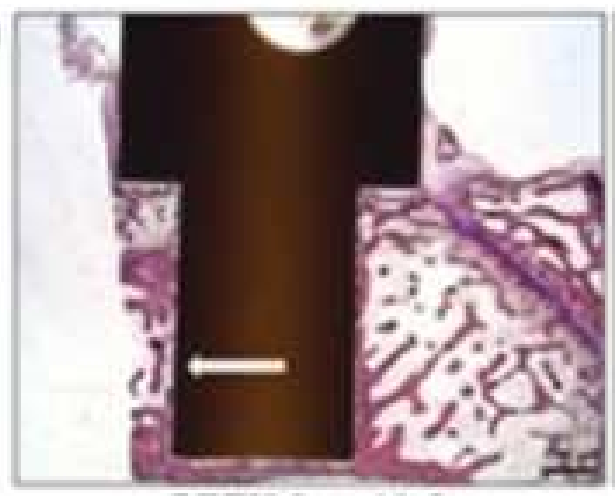

PEEK 8w $\times 12.5$

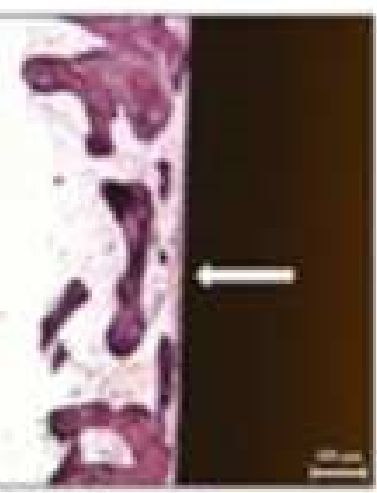

PEEK $8 \mathrm{w} \times 40$

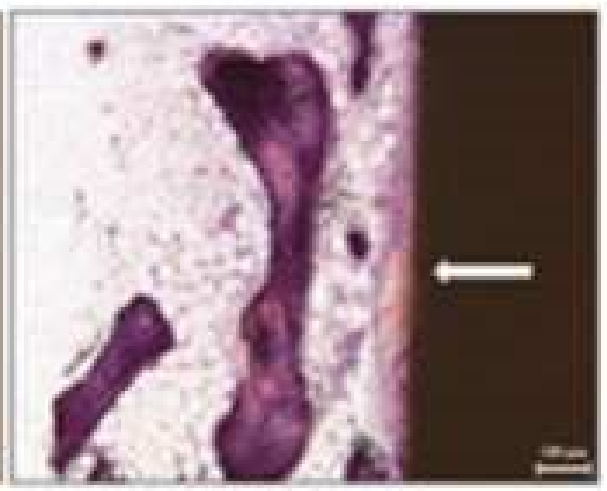

PEEK $8 w \times 100$

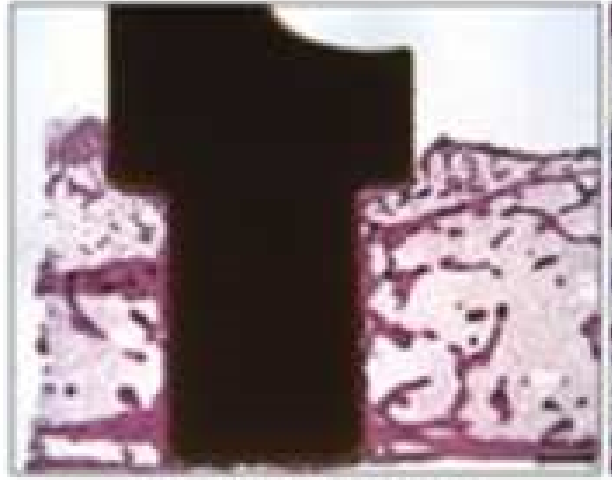

HA-PEEK 8 w 812.5

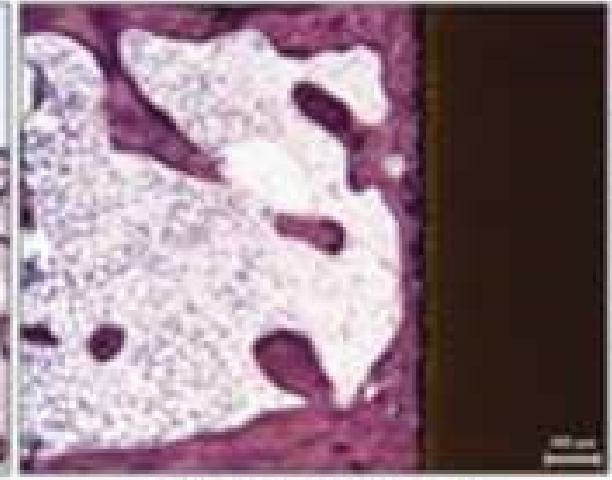

HA-PEEK $8 \mathrm{w} \times 40$

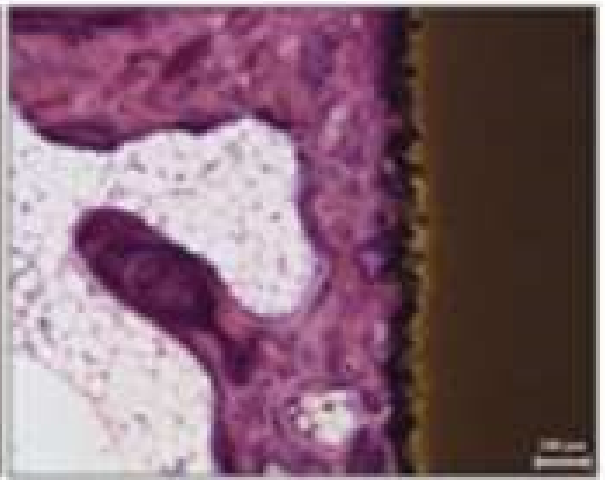

HA-PEEK 8 w $\times 100$ 
Click here to download Table: TABLE.docx

Table 1

Requirements of HA coatings for implants for surgery [61-65]

\begin{tabular}{lc}
\hline \multicolumn{1}{c}{ Property } & Specification \\
\hline $\mathrm{Ca} / \mathrm{P}$ ratio & $1.67-1.76$ \\
\hline Hydroxyapatite phase & $\geq 50 \%$ \\
\hline Limits of specific trace elements & $50 \mathrm{mg} / \mathrm{kg}$ \\
\hline Hydroxyapatite phase & $>50 \%$ \\
\hline TCP, TTCP, CaO phases & $\leq 5 \%$ mass fraction \\
\hline Crystallinity & $\geq 45 \%$ of the $100 \%$ crystalline hydroxyapatite \\
\hline Tensile Strength & $\geq 15 \mathrm{MPa}$ \\
\hline Shear Strength & $\geq 22 \mathrm{MPa}$ \\
\hline
\end{tabular}


Table 2

Advantages and inconvenients of TS to other technologies for HA spraying [66-69]

\begin{tabular}{|c|c|c|}
\hline Technique & Advantages & Inconvenients \\
\hline Thermal spraying & $\begin{array}{l}\text {-High deposition rates } \\
\text {-Low cost }\end{array}$ & $\begin{array}{l}\text {-Line of sight technique } \\
\text {-High temperature induce decomposition } \\
\text {-Rapid cooling produces amorphous coatings } \\
\text {-Lack of uniformity } \\
\text {-Crack appearance } \\
\text {-Low porosity } \\
\text {-Coating spalling and interface separation between the } \\
\text { coating and the substrate }\end{array}$ \\
\hline Sputter coating & $\begin{array}{l}\text {-Uniform Coating thickness on flat } \\
\text { substrates } \\
\text {-Dense coating } \\
\text {-Homogenous coating } \\
\text {-High adhesion }\end{array}$ & $\begin{array}{l}\text {-Line of sight technique } \\
\text {-Expensive time consuming } \\
\text {-Produces amorphous coatings } \\
\text {-Low crystallite which accelerates the dissolution of the } \\
\text { film in the body }\end{array}$ \\
\hline $\begin{array}{l}\text { Pulsed laser } \\
\text { deposition }\end{array}$ & $\begin{array}{l}\text {-Coating with crystalline and amorphous } \\
\text { faces } \\
\text { - Dense and porous coating } \\
\text {-Ability to produce wide range of multilayer } \\
\text { coating from different materials } \\
\text {-Ability to produce high crystalline HA } \\
\text { coating } \\
\text {-Ability to restore complex stoichiometry } \\
\text {-High degree of control on deposition } \\
\text { parameters }\end{array}$ & $\begin{array}{l}\text {-Line of sight technique } \\
\text {-Splashing or particle deposition } \\
\text {-Need surface pretreatment } \\
\text {-Lack of uniformity }\end{array}$ \\
\hline Dip coating & $\begin{array}{l}\text {-Low cost } \\
\text {-Quick technique } \\
\text {-Produce complex coat substrates } \\
\text {-High surface uniformity } \\
\text {-Good speed of coating }\end{array}$ & $\begin{array}{l}\text {-Requires high sintering temperatures } \\
\text {-Thermal expansion mismatch } \\
\text {-Crack appearance }\end{array}$ \\
\hline Sol-Gel & $\begin{array}{l}\text {-Can coat complex shapes } \\
\text {-Low processing temperatures } \\
\text {-Relatively cheap as coatings are very thin } \\
\text {-Simple deposition method } \\
\text {-High purity } \\
\text {-High corrosion resistant } \\
\text {-Fairly good adhesion }\end{array}$ & $\begin{array}{l}\text {-Some processes require controlled atmosphere processing } \\
\text {-Expensive raw materials } \\
\text {-Not suitable for industrial scale } \\
\text {-High permeability } \\
\text {-Low wear resistance } \\
\text {-Hard to control the porosity }\end{array}$ \\
\hline $\begin{array}{l}\text { Electrophoretic } \\
\text { deposition }\end{array}$ & $\begin{array}{l}\text {-Uniform coating thickness } \\
\text {-Rapid deposition rates } \\
\text {-Can coat complex substrates } \\
\text {-Simple setup } \\
\text {-Low cost } \\
\text {-High degree of control on coating } \\
\text { morphology -and thickness } \\
\text {-Good mechanical strength } \\
\text {-High adhesion for n-HA }\end{array}$ & $\begin{array}{l}\text {-Difficult to produce crack-free coatings } \\
\text {-Requires high sintering temperatures } \\
\text {-HA decomposition during sintering stage } \\
\text {-Substrate must have electrical conductivity }\end{array}$ \\
\hline $\begin{array}{l}\text { Hot isostatic } \\
\text { pressing }\end{array}$ & $\begin{array}{l}\text {-Produce dense coatings } \\
\text {-Produce net-shape ceramics } \\
\text {-Good temperature control } \\
\text {-Homogeneous structure } \\
\text {-High uniformity } \\
\text {-High precision } \\
\text {-No dimensional or shape limitation } \\
\end{array}$ & $\begin{array}{l}\text {-Cannot coat complex substrates } \\
\text {-High temperature required } \\
\text {-Thermal expansion mismatch } \\
\text {-Elastic property differences } \\
\text {-Expensive } \\
\text {-Removal/interaction of encapsulation material }\end{array}$ \\
\hline $\begin{array}{l}\text { Ion beam assisted } \\
\text { deposition }\end{array}$ & $\begin{array}{l}\text {-Low temperature process } \\
\text {-High reproducibility and reliability } \\
\text {-High adhesion } \\
\text {-Wide atomic intermix zone are coating-to- } \\
\text { substrate interface }\end{array}$ & -Crack appearance on the coated surface \\
\hline $\begin{array}{l}\text { Dynamic mixing } \\
\text { method }\end{array}$ & -High adhesive strength & $\begin{array}{l}\text {-Line of sight technique } \\
\text {-Expensive } \\
\text {-Produces amorphous coatings }\end{array}$ \\
\hline Biomimetic coating & $\begin{array}{l}\text {-Low processing temperatures } \\
\text {-Can form bonelike apatite } \\
\text {-Can coat complex shapes } \\
\text {-Can incorporate gone growth stimulating } \\
\text { factors }\end{array}$ & $\begin{array}{l}\text {-Time consuming } \\
\text {-Requires replenishment and a constant of } \mathrm{pH} \text { of simulated } \\
\text { body fluid }\end{array}$ \\
\hline Solution deposition & $\begin{array}{l}\text {-A low-temperature precipitation process } \\
\text { resulting in a pure, highly crystalline, firmly } \\
\text { adherent HA coating. Good for coating } \\
\text { evenly for porous and beaded surfaces. }\end{array}$ & $\begin{array}{l}\text {-Maximum thickness of } 20 \text { microns limits its use as a } \\
\text { primary mode of fixation }\end{array}$ \\
\hline $\begin{array}{l}\text { Electrochemical } \\
\text { deposition (ECD) }\end{array}$ & $\begin{array}{l}\text {-Uniform coating } \\
\text {-Simply set up }\end{array}$ & $\begin{array}{l}\text { Low tear strength } \\
\text { Poor adherence }\end{array}$ \\
\hline
\end{tabular}




\begin{tabular}{|c|c|c|}
\hline & $\begin{array}{l}\text {-Control morphologies coating } \\
\text {-Low temperatures } \\
\text {-Coat highly irregular objects }\end{array}$ & \\
\hline $\begin{array}{l}\text { Atomic layer } \\
\text { deposition }\end{array}$ & $\begin{array}{l}\text {-Suitable for preparation nanoscale HA and } \\
\text { coating three-dimensional structures where } \\
\text { exact film conformality is needed }\end{array}$ & Poor crystallinity \\
\hline PVD & $\begin{array}{l}\text {-Thin layers } \\
\text {-More adherent to the underlying titanium } \\
\text { surface than thermal spray } \\
\text { less prone to crack formation }\end{array}$ & Expensive technique \\
\hline CVD & $\begin{array}{l}\text {-Ability to modulate precursor } \\
\text { concentrations during deposition to create } \\
\text { functionally graded coatings }\end{array}$ & Expensive technique \\
\hline
\end{tabular}


Table 3

The human impact and the size of the commercial market for biomaterials and medical devices [3]

\begin{tabular}{lll}
\hline \multicolumn{1}{c}{ Application } & \multicolumn{1}{c}{ Biomaterials used } & $\begin{array}{c}\text { Number/year - World (or } \\
\text { World Market in US\$) }\end{array}$ \\
\hline Joint replacements (hip, knee, shoulder) & Titanium, stainless steel, polyethylene & 2.500 .000 \\
\hline Bone fixation plates and screws & Metals, poly(lactic acid) (PLA) & 1.500 .000 \\
\hline Spine disks and fusion hardware & - & 800.000 \\
\hline Bone cement & Poly(menthyl methacrylate) & $(\$ 600 \mathrm{M})$ \\
\hline Bone defect repair & Calcium phosphates & - \\
\hline Artificial tendon or ligament & Polyester fibers & - \\
\hline Dental implant-tooth fixation & Titanium & $(\$ 4 \mathrm{~B})$ \\
\hline \multicolumn{1}{c}{ The biomaterials and healthcare market: Facts and figures (per year) } \\
\hline Total US healthcare expenditures (1990) & $\$ 714$ billion \\
\hline Total US healthcare expenditures (2009) & $\$ 2.5$ trillion \\
\hline Total US health research and development expenditure (2009) & $\$ 139$ billion \\
\hline Number of medical device companies in the US & 12.000 \\
\hline Jobs in the US medical device industry (2008) & 425.000 \\
\hline Sales by US medical device industry (2008) & $\$ 136$ billion \\
\hline World medical device market forecast for 2013 & $\$ 286$ billion \\
\hline
\end{tabular}


Table 4

Surface description of some of the commercial orthopedic implants [92]

\begin{tabular}{|c|c|}
\hline Manufacturer & Surface description \\
\hline \multirow[t]{2}{*}{ Biomet } & -Regenerex ${ }^{\mathrm{TM}}$ : porous Ti alloys \\
\hline & -RoughCoat ${ }^{\mathrm{TM}}$ : sintered Co-Cr bead porous coating with and without plasma-sprayed HA \\
\hline \multirow[t]{3}{*}{ DePuy } & -Oription ${ }^{\mathrm{TM}}$ : porous coating, porous pure Ti alloy coating \\
\hline & -Purocoat $(\mathbb{2}$ : porous coating, sintered $\mathrm{Co}-\mathrm{Cr}$ beads \\
\hline & -Duofix ${ }^{\circledR}$ HA: plasma sprayed HA over Purocoat ${ }^{\circledR}$ coating \\
\hline \multirow[t]{2}{*}{ Smith \& Nephew } & -Stikite: porous three-dimensional asymmetric Ti powder coating \\
\hline & -RoughCoat ${ }^{\mathrm{TM}}$ : sintered Co-Cr bead porous coating with and without plasma-sprayed HA \\
\hline \multirow[t]{5}{*}{ Stryker } & -PureFix ${ }^{\mathrm{TM}} \mathrm{HA}:$ plasma-sprayed HA \\
\hline & -Peri-Apatite ${ }^{\mathrm{TM}}$ : solution deposited HA coating that uniformly coats three-dimensional porous ingrowth \\
\hline & surfaces \\
\hline & -Plasma sprayed cpTi with and without PureFix ${ }^{\mathrm{TM}}$ HA coating \\
\hline & -Arc-deposited cpTi with PureFix ${ }^{\mathrm{TM}}$ HA coating \\
\hline \multirow[t]{4}{*}{ Zimmer } & -Trabecular Metal ${ }^{\mathrm{TM}}$ : open cell porous tantalum construct \\
\hline & -CSTi ${ }^{\mathrm{TM}}$, Cancellous-Structured Titanium ${ }^{\mathrm{TM}}$ coating with and without plasma-sprayed HA coating \\
\hline & -Fiber metal: Ti fiber with and without plasma-sprayed HA/TCP coating \\
\hline & -CoCr-beaded ingrowth surfaces \\
\hline Arcam AB & -Trabecular Structures TM $:$ titanium deposition via Electron Beam Melting (EBM) \\
\hline Astra Tech AB & OsseoSpeed ${ }^{\mathrm{TM}}$ : grit blasting titania $\left(\mathrm{TiO}_{2}\right)$, followed by hydrofluoric acid $(\mathrm{HF})$ treatment \\
\hline $\begin{array}{l}\text { BIOMET } 3 \mathrm{i} \\
\text { Implant Innovations }\end{array}$ & Nanotite $^{\mathrm{TM}}$ : CaP nanoparticle features \\
\hline
\end{tabular}


Table 5

CS conditions of metals coatings for biomedical applications

\begin{tabular}{|c|c|c|c|c|c|c|c|}
\hline & $\begin{array}{c}\text { Feedstock } \\
\text { powder }\end{array}$ & Substrate & Gas & $\begin{array}{c}\text { Gas temperature } \\
\qquad\left[{ }^{\circ} \mathrm{C}\right]\end{array}$ & $\begin{array}{c}\text { Gas pressure } \\
\text { [bars] }\end{array}$ & $\begin{array}{c}\text { Standoff } \\
\text { distance }[\mathrm{mm}]\end{array}$ & $\begin{array}{c}\text { Traverse } \\
\text { Speed }[\mathrm{mm} / \mathrm{s}]\end{array}$ \\
\hline Li et al.[113] & $\begin{array}{c}\text { Ti } \\
\text { Ti6Al4V }\end{array}$ & Ti6Al4V & Air & 520 & 28 & 30 & - \\
\hline Sun et al.[116] & $\mathrm{Ti}+\mathrm{Mg}$ & Titanium & $\mathrm{He}$ & 340 & 10 & - & - \\
\hline Qiu al.[117] & $\begin{array}{c}\mathrm{CpTi}+\mathrm{CpAl} \\
\mathrm{CpTi}+\mathrm{CpAl}+\mathrm{HA}\end{array}$ & $\mathrm{Ti}$ & $\mathrm{He}$ & 370 & 6.9 & 12.5 & 1.66 \\
\hline $\begin{array}{l}\text { Al-Mangour et } \\
\text { al. [120] }\end{array}$ & $\begin{array}{c}\text { SS 316+ } \\
\text { L605alloy }\end{array}$ & $\begin{array}{l}\text { Mild } \\
\text { Steel }\end{array}$ & $\mathrm{N}_{2}$ & 700 & 40 & 80 & 300 \\
\hline
\end{tabular}


Table 6

CS conditions of HA/Ti and HA coatings for biomedical applications

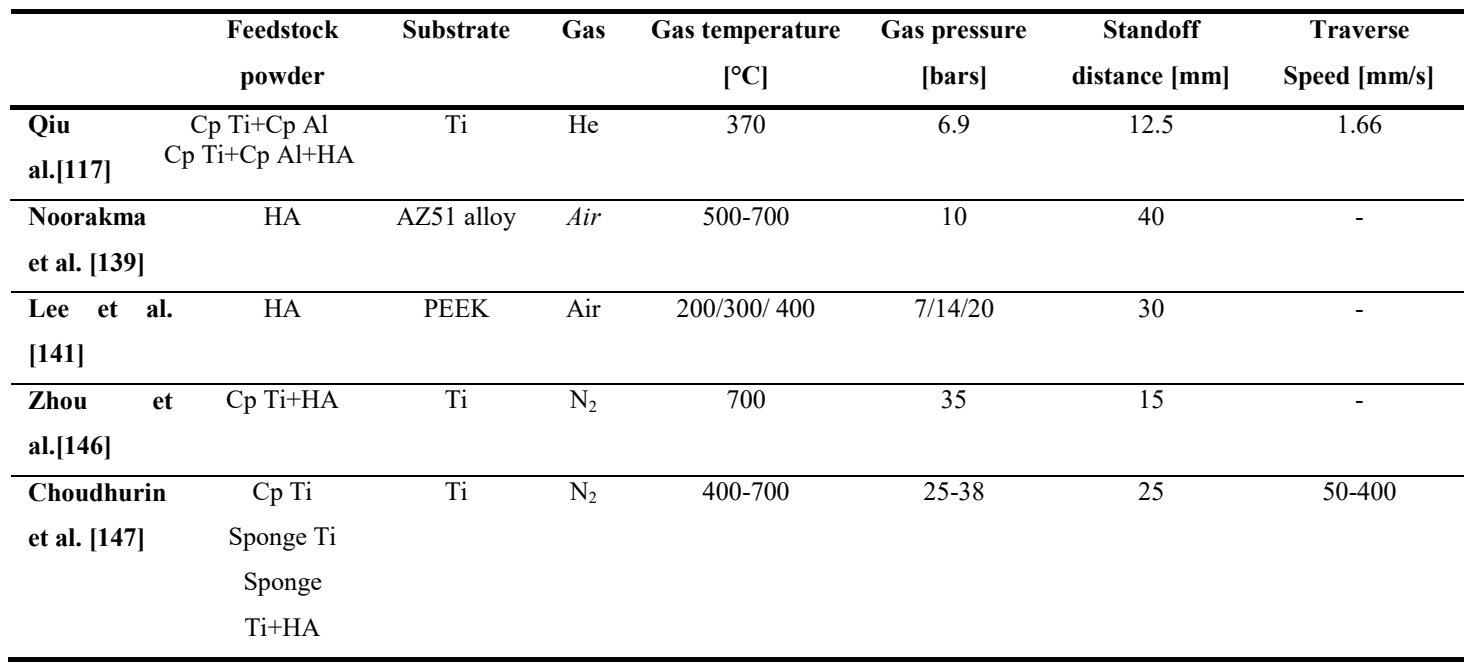


Table 7

CS conditions of antibacterial coating

\begin{tabular}{|c|c|c|c|c|c|c|c|}
\hline & $\begin{array}{c}\text { Feedstock } \\
\text { powder }\end{array}$ & Substrate & Gas & $\begin{array}{c}\text { Gas temperature } \\
\qquad\left[{ }^{\circ} \mathrm{C}\right]\end{array}$ & $\begin{array}{c}\text { Gas pressure } \\
\text { [bars] }\end{array}$ & $\begin{array}{c}\text { Standoff } \\
\text { distance }[\mathrm{mm}]\end{array}$ & $\begin{array}{c}\text { Traverse } \\
\text { Speed }[\mathrm{mm} / \mathrm{s}]\end{array}$ \\
\hline $\begin{array}{l}\text { Sanpo et all. } \\
{[149]}\end{array}$ & $\begin{array}{c}\text { HA-Ag } \\
\text { (Ag-doped } \\
\text { HA) } \\
\text { +PEEK }\end{array}$ & Glass & Air & $150-160$ & $11-12$ & 15 & 50 \\
\hline $\begin{array}{ll}\text { Tami et } & \text { et } \\
\text { all.[155] } & \end{array}$ & $\begin{array}{l}\text { Novaron } \\
\text { VZ } 600\end{array}$ & $\mathrm{Ti}$ & $\mathrm{N}$ & 350 & 30 & 5 & 20 \\
\hline
\end{tabular}


